\title{
تداعيات جائحة كورونا المستجد على القطاع السياحي المصري
}

\section{$*$}

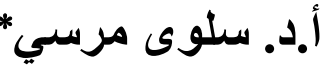

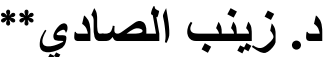

\section{مقدمة}

تواصل آثار تفشي جائحة فيروس كورونا المستجد (COVID-19) في معظم دول العالم تمددها واتساع نطاقها لتشمل العديد من الأنشطة الاقتصادية وأسواق المال. كما تم إلغاء العديد من الفعاليات العالمية الكبرى للحد من انتشار الفيروس، أو بسبب فرض قيود السفر التي فرضتها العديد من الدول وتعليق خطوط الطيران بها، مما أدى إلى تكبد شركات الطيران وشركات السياحة

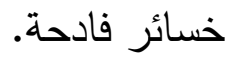

وبسبب جائحة هذا الفيروس يعاني قطاع السياحة حالياً في العالم حالة من الثلل التام. وعلى الرغم من جهود العديد من الدول المختلة للتخفيف من الأثر الاقتصادي لهذا الفيروس، فإن قطاع السياحة لن يتمكن من التعافي إلا بعد أن تتم السيطرة على هذا الفيروس ومن ثم رفع حظر السفر بصورة آمنة للمواطنين. وتجدر الإشارة إلى أنه كلما طال أمد هذه الأزمة الصحية، كلما تزايدت صعوبة استمرار العديد من الأنشطة السياحية وقدرتها على الاستمرار، وبخاصة الثركات الصغيرة والمتوسطة التي تشكل نسبة كبيرة من قطاع السياحة. سوف تتناول هذه الورقة دراسة تداعيات فيروس كورونا المستجد على القطاع السياحي الدصري، وذللك من خلال النقاط الرئيسية التالية: أولاً: الأهمية الاقتصادية للقطاع السياحي ثانيًا: تطور القطاع السياحي في الفترة من عام 2010 حتى عام 2019

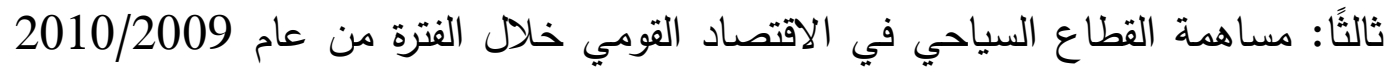
حتى عام 2019/2018 رابعًا: أثر تفشي فيروس كورونا المستجد (COVID-19) على القطاع السياحي العالمي

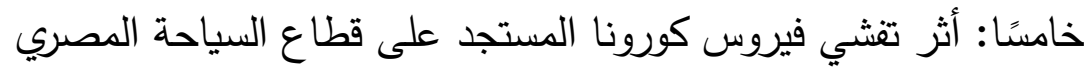
سادسًا: جهود مصر لمواجهة آثار جائحة كورونا 


\section{سابعًا: السيناريوهات المتوقعة للقطاع السياحي المصري خلال عام 2020 ثامنًا: مقترحات للتخفيف من آثار الأزمة على القطاع السات السياحي}

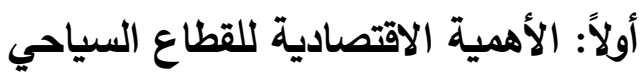

تعتبر السياحة أحد أهم القطاعات الاقتصادية ليس فقط على المستوي الدولي وإنما أيضًا على المستوي القومي والمحلي، وذلك لما لليها من قدرة على تحقيق النمو والتنمية الاقتصادية والاجتماعية للمجتمعات المحلية، نظرًا لتداخل وتثابك أنشطتها مع العديد من الصناعات والقطاعات الأخرى. ويعد القطاع السياحي أحد الدصادر الهامة للدخل القومي والعملة الأجنبية للاقتصاد المصري، وذلك لما تتمتع به مصر من العديد من المقومات السياحية مثل السياحة الثقافية والدينية والترفيهية وسياحة المؤتمرات والسفاري والسياحة البيئية والعلاجية وغيرها من

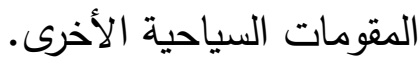

وترجع أهمية القطاع السياحي أيضا إلى قدرته في حث النشاط الاقتصادي على نطاق واسع، وذللك يرجع إلى قدرته في إقامة الروابط الأمامية والخلفية مع القطاعات الأخرى، فهذه الروابط تحفز من أثر المضاعف الذي تترتب علية فوائد اقتصادية كبيرة على الاقتصاد القومي وخلق فرص عمل

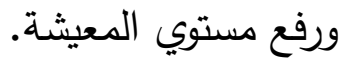

ثانياً: تطور القطاع السياحي في الفترة من عام 2010 حتى عام 2019 يعد القطاع السياحي قطاعًا حساسًا للغاية حيث أنه يتأثر تأثراً شديداً بالأحداث المحلية والعالمية. لذللك يتعرض هذا القطاع في مصر الآن لأزمة كبيرة بسبب تفشي فيروس كورونا المستجد. وقبل الحديث عن التتاعيات السلبية لهذا الفيروس على القطاع السياحي المصري سوف نلقي نظرة سريعة على تطور القطاع السياحي خلال الفترة من عام 2010 حتى عام 2019 والأزمات المختلفة التي تعرض لها هذا القطاع.

لقد تعرض القطاع السياحي المصري إلى العديد من الأزمات خلال السنوات القليلة الماضية، والتي أدت إلى تدهور هذا القطاع اعتبارا من عام 2011 (ثرة 25 يناير) وكذلك أزمة طائرة الركاب الروسية في عام 2015 وبعض حوادث الإرهاب المختلفة خلال عامي 2016 و 2017. والثكل رقم (1) يوضح لنا تطور أعداد السائحين القادمين إلى مصر خلال الفترة من عام 2010 حتى عام 2019 حيث يتضح: - n 
• بلغ عدد السائحين 14.7 مليون سائح عام 2010 ثم حدث انخفاض شديد لأعداد السائحين خلال السنوات 2011 و 2013 و 2015 و2016.

• زيادة عدد السائحين بنسبة 53\% في عام 2017 مقارنة بعام 2016، واستمرار هذه الزيادة

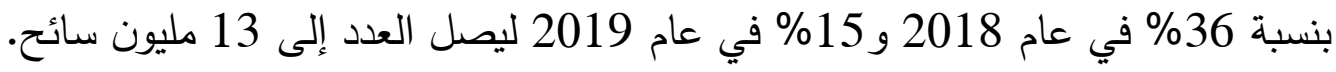
شكل رقم (1) أعداد السائحين في الفترة من عام 2010 حتى عام 2019

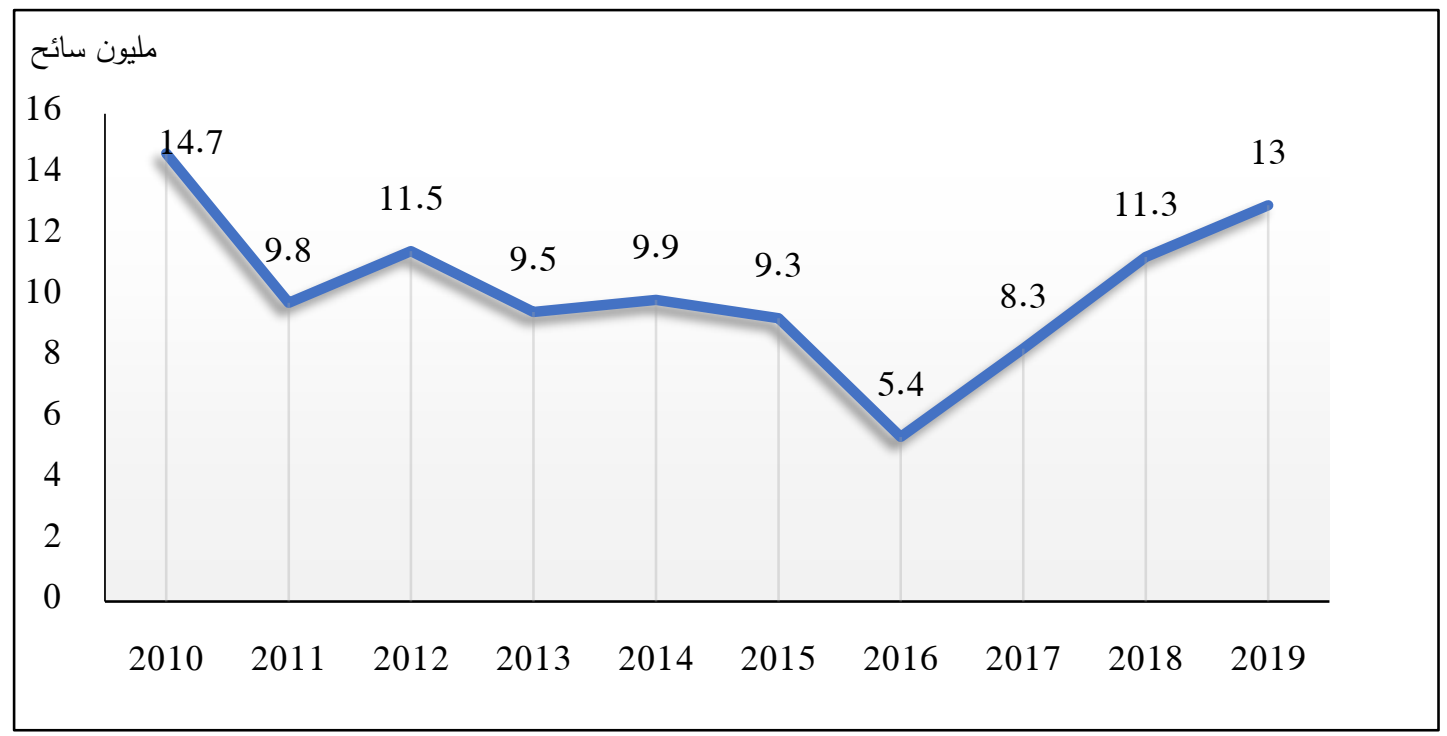

المصدر: الجهاز المركزي للتعبئة العامة والإحصاء، الكتاب الإحصائي السنوي، أعداد مختلفة.

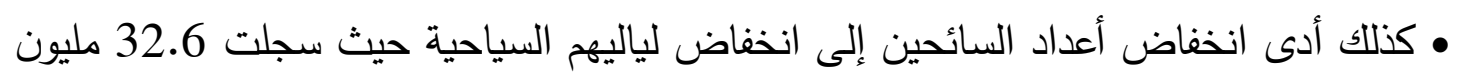

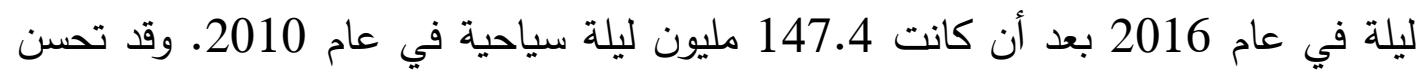

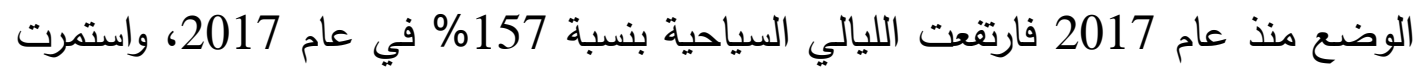

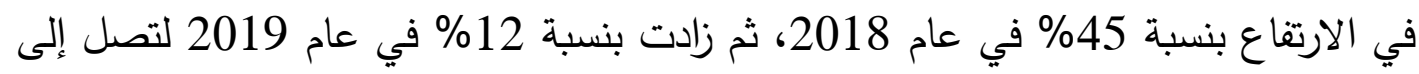
136.2 مليون ليلة 1.

وفيما يخص الإيرادات السياحية فقد تأثرت تأثراً شديداً خلال السنوات السابقة نتيجة لانخفاض أعداد السائحين وطبقا للشكل رقم (2) يتضح ما يلي: هجلت الإيرادات السياحية أدنى انخفاض لها في عام 2016 حيت بلغت 6 مليار دولار فقط.

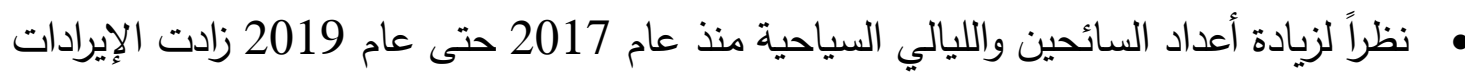

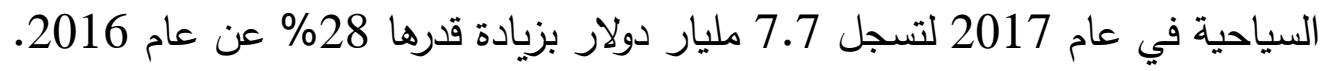
• استمرت الإيرادات السياحية في الزيادة بعد ذللك لترتفع إلى 12.6 مليار دولار عام 2019. 
شكل رقم (2) الإيرادات السياحية في الفترة من 2010 حتى عام 2019

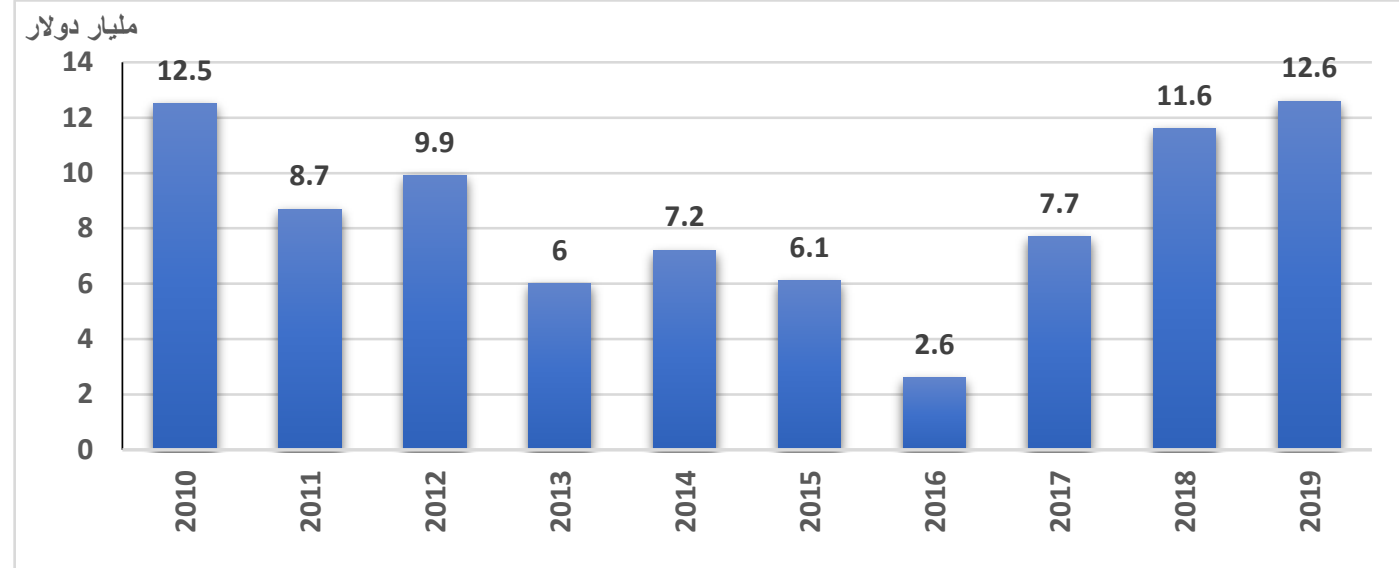

المصدر : البنك المركزي المصري، التقرير السنوي، أعداد مختلفة.

ثالثاً: مساهمة القطاع السياحي في الاقتصاد القومي خلال الفترة من عام 2010/2009 حتى عام 2019/2018

يلعب القطاع السياحي دوراً هاماً في الاقتصاد القومي من حيث مساهمته في الحد من العجز التجاري والمتحصلات الخدمية وفي إجمالي الصادرات.

1-مساهمة القطاع السياحي في الميزان التجاري ساهم القطاع السياحي في الميزان التجاري عام 2010/2009 بنسبة 46\% وهي أعلي نسبة وصلت إليها خلال فترة الدراسة. ألا أن هذه المساهمة انخفضت كثيراً في عام 2016/2015 حيث بلغت 10\% فقط، ثم عادت للارتفاع مرة أخري لتسجل 20\% في عام 2018/2017 و 30\% في عام 2019/2018.

2- مساهمة القطاع السياحي في ميزان الخدمات والمتحصلات الخدمية ساهم القطاع السياحي في ميزان الخدمات بنسبة كبيرة بلغت 85\% في عام 2009/2008، تم انخفضت بعد ذلك لتصل إلى 57\% في عام 2016/2015، ثم ارتفعت مرة أخري لتصل إلى 89 في عام 2019/2018. أما عن مساهمة القطاع السياحي في المتحصلات الخدمية فقد 
بلغت هذه النسبة 51\% في عام 2010/2009، إلا أنها انخفضت لتصل إلى 23\% في عام

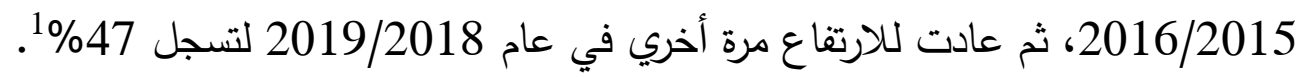
3-مساهمة القطاع السياحي في إجمالي الصادرات بلغت نسبة مساهمة القطاع السياحي في إجمالي الصادرات 48\% خلال عام 2010/2009، ثم انخفضت في السنوات التالية لتصل إلى 20\% في عام 2017/2016 ثم عاودت الارتفاع مرة أخري لتصل إلى 30\% في عام 2018/2017 ثم إلى 40\% في عام 2019/2018. وبذلك يمكن القول إن للقطاع السياحي دورا هاما في الاقتصاد القومي عن طريق مساهمته ألفعالة في ميزان الخدمات والمتحصلات الخدمية والحد من العجز التجاري. لذلك فإن الاستقرار السياسي والاقتصادي والصحي والبيئي يساعد على نمو وتطور القطاع السياحي وزيادة مساهته في التنمية

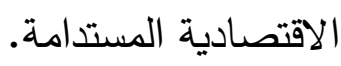

4-مساهمة القطاع السياحي في الناتج المحلي الإجمالي وزيادة فرص العمل. ساهم القطاع السياحي المصري في الناتج المحلي الإجمالي (المساهمة المباشرة وغير المباشرة) بحوالي 12\% خلال عام 2019، ومن المتوقع أن تقل هذه النسبة هذا العام بسبب تفشي جائحة كورونا. كذللك يساهم القطاع السياحي في خلق العديد من فرص العمل المباشرة وغير المباشرة حيث يقدر عدد العاملين في القطاع السياحي بحوالي 3 مليون عامل (عمالة مباشرة وغير مباشرة) وهو ما يمثل حوالي 10\% من إجمالي قوة العمل.

رابعاً: أثر تفشي فيروس كورونا المستجد (COVID-19) على القطاع السياحي العالمي أدى انتشار فيروس كورونا المستجد في معظم دول العالم إلى الأضرار بالعديد من القطاعات الإنتاجية والاقتصادية والاجتماعية ومن ثم تكبدها خسائر كبيرة. ويعد قطاع السياحة والسفر العالمي واحد من أكثر القطاعات الاقتصادية التي تكبدت خسائر فادحة نتيجة انتشار هذا الفيروس، حيث توقفت حركة السياحة والطيران بشكل كامل في فترة وصلت إلى حوالي 4 أشهر (منذ فبراير 2020) حتى الآن. وتجدر الإثارة إلى أن القطاع السياحي العالمي يشهـ أزمة لم يعاصرها منذ الحرب العالمية الثانية، مما أدى إلى لجوء العديد من الدول لتخفيض خططها المتوقعة للعام الحالي 
2020 وسط نظرة متشائمة لمستقبل النشاط السياحي الذي تمثل إيراداته بنداً مهما في اقتصاديات العديد من الدول. وقبل الحديث عن الخسائر المتوقعة للقطاع السياحي العالمي هذا العام نتيجة لفيروس كورونا المستجد، نستعرض وضع السياحة العالمية خلال السنوات القليلة الماضية حتى نستطيع أن نري أثر هذا الوباء عليه.

طبقا لمنظمة السياحة العالمية فإن عدد السائحين في العالم بلغ 1.33 مليار سائح عام 2017 والذي ارتفع بنسبة 4\% في عام 2018 ليصل إلى 1.4 مليار سائح تم ارتفع مرة أخري بنسبة 4 أيضا في عام 2019 ليصل إلى 1.46 مليار سائح'. وفيما يخص الإيرادات السياحية العالمية فطبقا لمنظمة السياحة العالمية فأن الإيرادات ارتفعت من 1.3 ترليون دولار في عام 2017 إلى 1.45 ترليون دولار في عام 2017 وأخيرا بلغت 1.48 ترليون دولار في عام 2019². ورغم أن كل الد لائل كانت تشير إلى أن قطاع السياحة العالمي سوف يستمر في النمو عام 2020 بنسبة 4\% مثل العام السابق 2019، إلا أن فيروس كورونا المستجد الذي ظهر في أواخر ديسمبر 2019 في الصين قلب كل الموازين وأدى إلى حدوث خسائر كبيرة في معظم دول العالم. وطبقا لآخر إحصائيات منظمة الصحة العالمية، فإن عدد إصابات كورونا في العالم وصل إلى أكثر من 4.5 مليون مصاب، وعدد الوفيات وصل إلى 307 ألف وفاة. وقد أصاب هذا الفيروس أكثر من 200 دولة حول العالم. كذلك أشار هذا التقرير إلى أن أكثر دول العالم تضرراً من هذا الفيروس إلى هي الولايات المتحدة الأمريكية التي سجلت مليون و 477 ألف إصابة وأكثر من 88 ألف وفاة. وتأتي بعدها أسبانيا بحوالي 274.3 ألف إصابة و 27.4 ألف وفاة، ثم روسيا بأكثر من 262.8 مأد

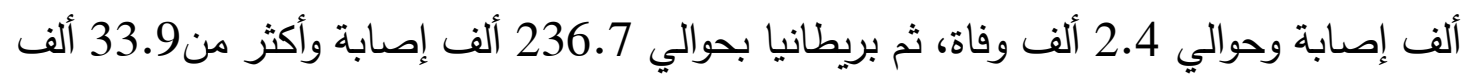
وفاة، ثم إيطاليا بعدد 223.8 ألف إصابة و31.6 ألف وفاة، ثم فرنسا بعدد 178.8 ألف إصابة وأكثر من 27 ألف وفاة، وأخيرا ألمانيا بأكثر من 175.7 ألف إصابة وأكثر من 8 آلاف وفاة3 وتجدر الإشارة إلى أنه في بداية هذا العام 2020 وقبل ظهور فيروس كورونا المستجد توقعت

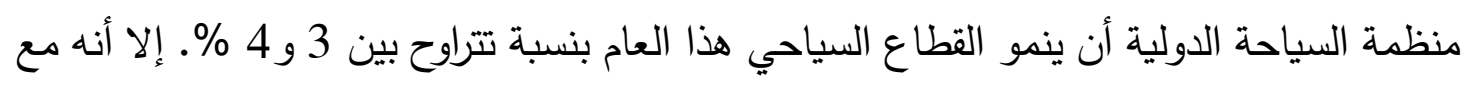

\footnotetext{
${ }^{1}$ The World Tourism Organization, UNWTO World Tourism Barometer- Special focus on the Impact of COVID-19 ،May 2020

المرجع السابق

3 World meters website, retrieved 15 May 2020 !https://www.worldometers.info/coronavirus/
} 
انتشار فيروس كورونا في العديد من الدول وزيادة عدد الإصابات والوفيات، قامت العديد من الدول بعمل إجراءات احترازية مشدة مثل إغلاق الحدود، وتعليق الرحلات الجوية، وفرض حظر تجوال، وتعطيل الدراسة، وإلغاء الفعاليات، وإغلاق دور العبادة. لذلك قامت منظمة السياحة العالمية بتعديل توقعاتها السابقة وتوقعت الآتي:

• في نهاية شهر مارس 2020 ومع استمرار غلق الحدود وتعليق الرحلات الجوية في معظم

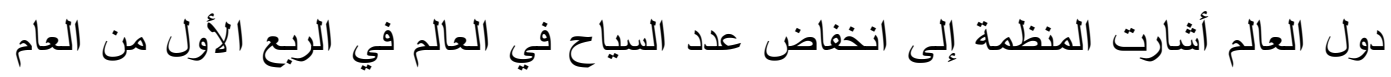

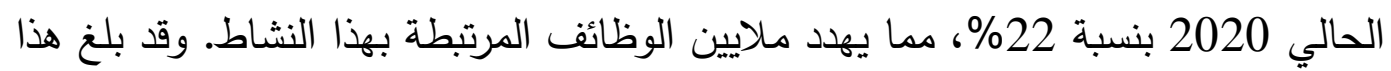

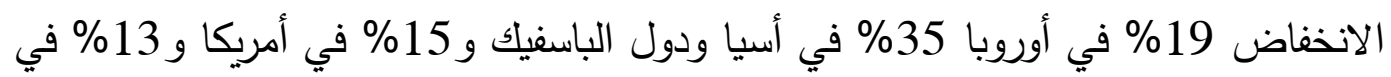
أفريقيا و 11\% في الشرق الأوسط. • من المتوقع تراجع الإيرادات السياحية العالمية هذا العام ما بين 910 بليون دولار و1.2 تريليون دولار . • توقعت المنظمة أن يتسبب هذا الوباء في الإطاحة بحوالي 50 مليون وظيفة سياحية على ترلى

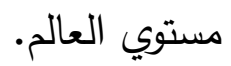
• مع بداية شهر مايو 2020 أشارت منظمة السياحة العالمية إلى أن انخفاض أعداد السائحين في العالم قد بلغ 57\% في شهر مارس الماضي. وبناء على ذلك وضعت منظمة السياحة العالمية ثلاث سيناريوهات للوضع السياتي العياحي العالمي خلال عام 2020 طبقا لتوقعات الفتح التدريجي وفتح الحدود بين الدول وهي كالتالي 1: السيناريو الأول: في حالة الفتح التدريجي للحدود وتخفيف قيود السفر وبدء رحلات الطيران الداخلي في بداية شهر يوليو 2020 سوف يصل الانخفاض في عدد السياح إلى حوالي 58\% فقط بالمقارنة بعام 2019.

السيناريو الثاني: في حالة أن يتم الفتح التدريجي للحدود وتخفيف قيود السفر وبدء الطيران الداخلي في بداية شهر سبتمبر 2020 فإن انخفاض أعداد السائحين سوف يصل إلى 70\% بالمقارنة لعام 2019 وهذا ما يتوقعه العديد من الخبراء. السيناريو الثالث: إذا استمرت الأمور كما هي حتى بداية ديسمبر 2020 فإن ذلك يعني خسائر كبيرة للنشاط السياحي وانخفاض في أعداد السائحين بنسبة 78\%.

${ }^{1}$ World Tourism Organization, UNWTO :International Tourism Arrivals Could Fall By $\mathbf{2 0 - 3 0 \%}$ IN 2020, news release, 27 March.2020 ، 
طبقاً للسيناريو الأول فمن المتوقع أن ينخفض عدد السائحين بحوالي 850 مليون سائح، ويصل هذا الانخفاض إلى 1020 مليون سائح طبقاً للسيناريو الثاني و 1140 مليون سائح طبقاً للسيناريو

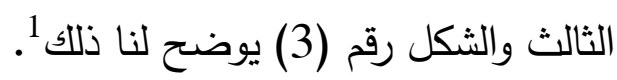
شكل رقم (3) السيناريوهات المقترحة لإعداد السائحين في العالم في ظل تفشي وباء كورونا

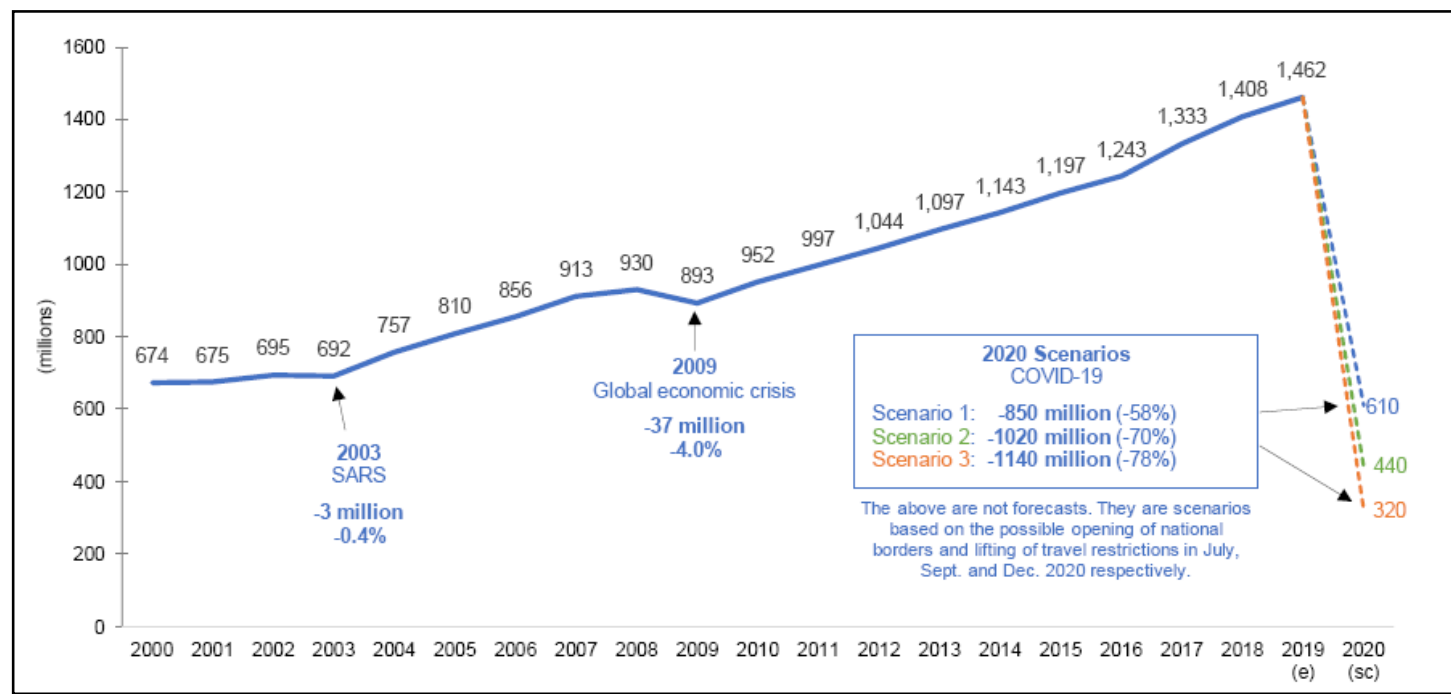

المصدر:

The World Tourism Organization, UNWTO World Tourism Barometer- Special focus on the Impact of COVID-19 ،May 2020 ،P17

بالنسبة للإيرادات السياحية والتي كانت قد سجلت 1.48 ترليون دولار في عام 2019، فمن المتوقع أن تتخفض بنسبة 62\% طبقاً للسيناريو الأول ليصل هذا الانخفاض إلى 910 بليون دولار وبنسبة 73\% طبقاً للسيناريو الثاني ليصل هذا الانخفاض إلى 1080 بليون دولار أما إذا وصلنا إلى السيناريو الثالث فسوف تسجل هذه الإيرادات انخفاضا بنسبة 79\% لتصل إلى 1170 بليون دولار والثكل رقم (4) يوضح لنا ذللك.

\footnotetext{
${ }^{1}$ The World Tourism Organization, UNWTO World Tourism Barometer-Special focus on the
} Impact of COVID-19 ،May, 2020 . 
شكل رقم (4) السيناريوهات المقترحة للإيرادات السياحية العالمية في ظل تفشي وباء كورونا

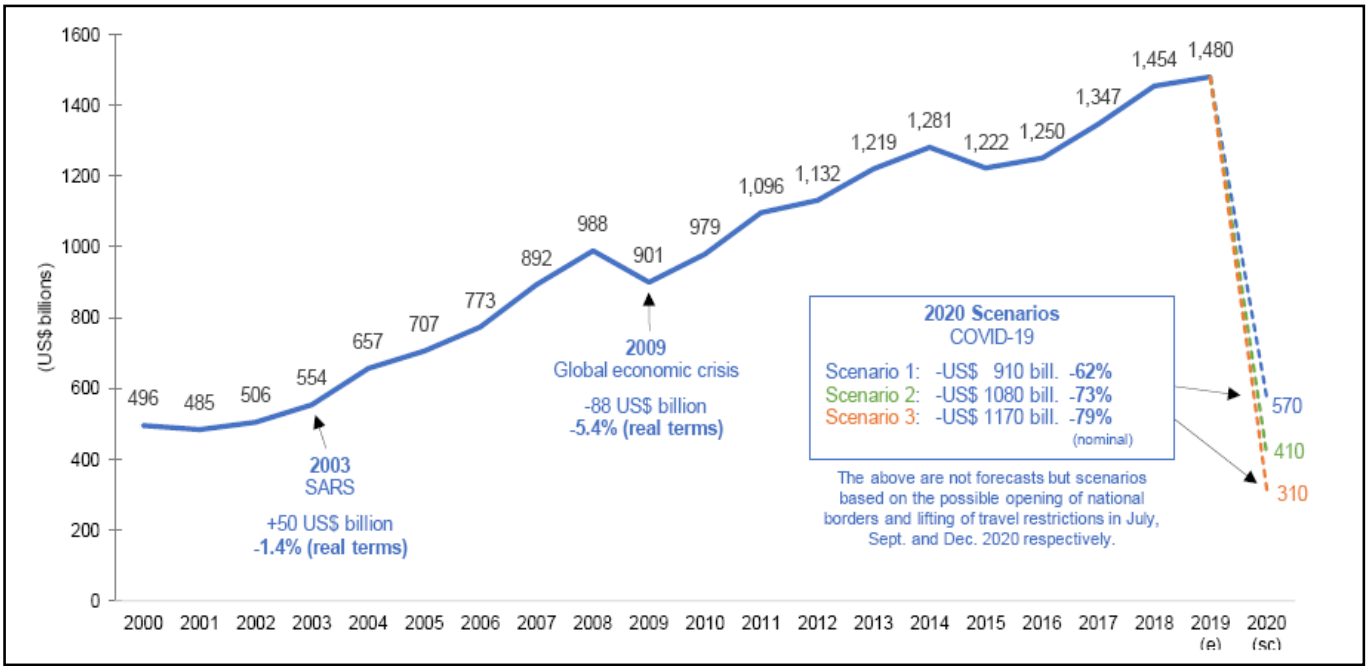

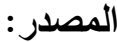

The World Tourism Organization, UNWTO World Tourism Barometer -Special focus on the Impact of COVID-19, May 2020, P18

وأخيرا يمكن القول إن انتشار فيروس كورونا المستجد سوف يؤدي إلى انخفاض أعداد السائحين خلال عام 2020 ما بين 850 مليون و 1.1 بليون سائح. وسوف يؤدي أيضاً إلى انخفاض الإيرادات السياحية ما بين 910 بليون دولار إلى 1.2 ترليون دولار ـ أما عدد الوظائف التي سوف تتأثر من هذا الفيروس خلال هذا العام فسوف تتراوح ما بين 100 إلى 120 مليون وظيفة. وبالإضافة إلى خسائر القطاع السياحي العالمي، فإن الاتحاد الدولي للنقل الجوي (IATA) قد أشار إلى أن الخسائر المتوقعة للنقل الجوي الدولي في ظل ظروف انتشار فيروس كورونا المستجد هي كالآتي

• حجم الخسائر المتوقعة لشركات الطيران في العالم تقدر بأكثر من 252 مليار دولار • • سوف تؤدي هذه الأزمة إلى انخفاض قدرة صناعة الطيران بأكثر من 30\% خلال عام .2020 • مع استمرار هذه الأزمة لعدة أشهر أخري فإن ذلك سوف يؤدي إلى تعرض العديد من شركات الطيران في العالم لخطر الإفلاس. • حجم الخسائر المتوقعة على إيرادات قطاع الطيران في منطقة الشرق الأوسط وأفريقيا تقدر بحوالي 24 مليار دولار بالإضافة إلى تعرض 1.2 مليون وظيفة في قطاع الطيران والقطاعات المرتبطة به للخطر بـ

${ }^{1}$ International Air Transport Association (IATA), Air Passenger Market Analysis, March 2020. 
• من المتوقع أن تصل خسائر الاقتصادات المدعومة بقطاع الطيران في منطقة الثرق الأوسط

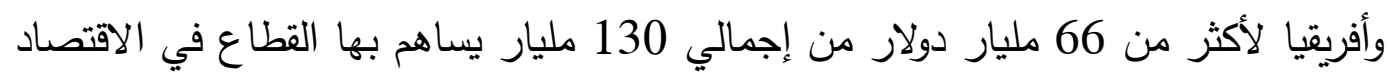
المحلي لدول المنطقة.

خامساً: أثر تفثي فيروس كورونا المستجد على قطاع السياحة المصري

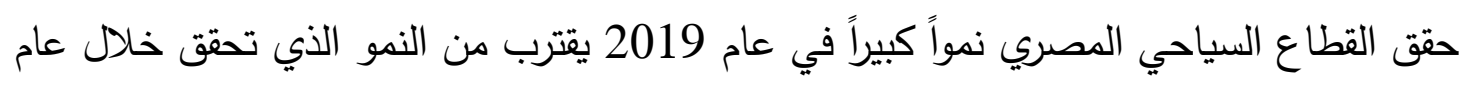

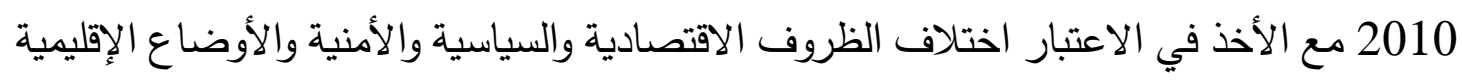
والأزمات المختلفة التي تعرض لها هذا القطاع منذ أحداث يناير 2011 وما بعدها. وتشير الإحصاءات إلى أن عدد السائحين في عام 2019 بلغ 13 مليون سائح مقابل 11.3

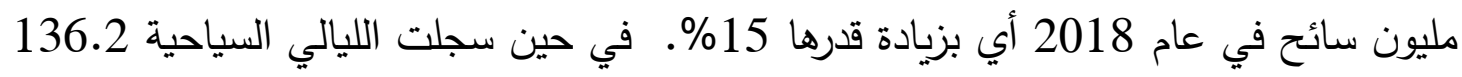
مليون ليلة في عام 2019 مقابل 121.5 مليون ليلة في عام 2018 بزيادة قدرها 12. 12.

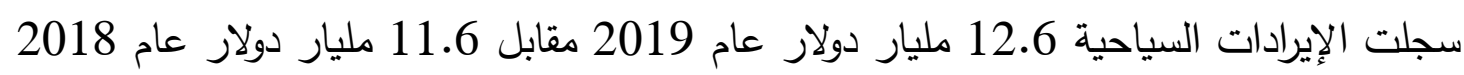

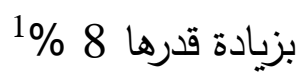

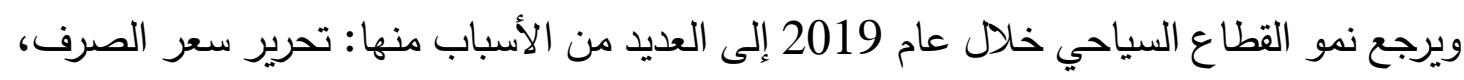
ومبادرة البنك المركزي لتمويل، وتجهيز العديد من الفنادق، وكذلك الاستقرار الأمني، والاهتمام

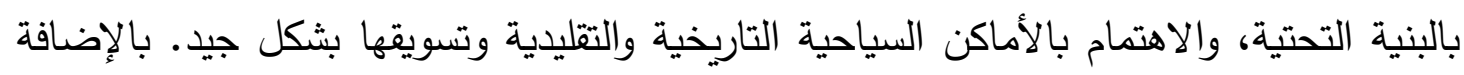

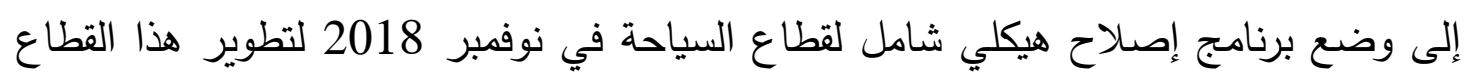
بهدف أحداث تتمية سياحية مستدامة ورفع قدرته التتافسية لتتماشي مع الاتجاهات العالمية وزيادة فئادير عدد العاملين به.

وقد ارتكز برنامج هذا الإصلاح على خمس محاور شملت الإصلاح المؤسسي والتشريعي وتطور

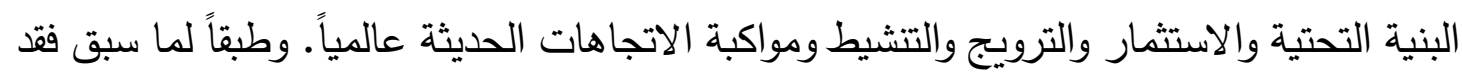

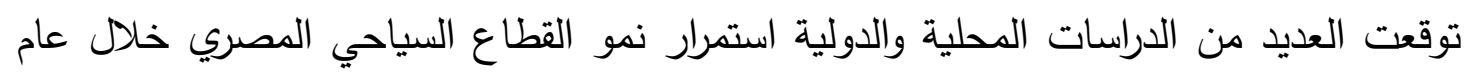
2020. حيث توقعت هذه الدراسات نمو عدد السياح بنسبة 15\% ليصل إلى ولى 15 مليون سائح عام 2020 مقابل 13 مليون سائح عام 2019. كذللك توقعت الدراسات نمو الليالي السياحية عام 2020 بنسبة 10\% لتصل إلى 150 مليون ليلة مقابل 136 مليون ليلة عام 2019 2019. ومع نمو

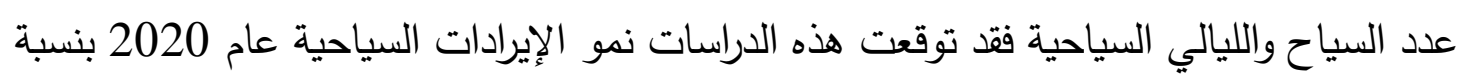

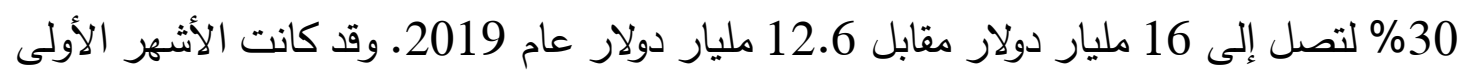
من هذا العام 2020 تشير إلى ذلك حيث بلغ عدد السائحين خلا الثلار ملابل أثهر الأولى من هذا 1 ا البنك المركزي المصري، النثرة الإحصائية الثهرية، أعاد مختلفة والجهاز المركزي للتعبئة العامية والاحصاء -مصر في ارقام 
العام حوالي 2.4 مليون سائح (2 مليون سائح خلال شهري يناير وفبراير و 400 ألف سائح خلال النصف الأول من شهر مارس) وقدرت الإيرادات السياحية في هذه الفترة بحوالي 2.5 مليار دولار 1.

ولكن مع الأسف أدى ظهور فيروس كورونا المستجد في معظم دول العالم وظهوره في مصر في

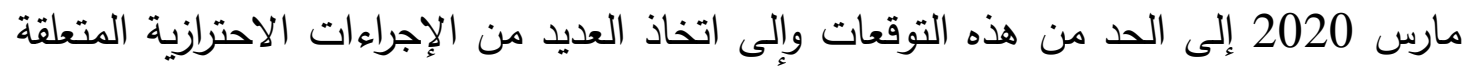
بالقطاع السياحي لمواجهة آثار هذه الجائحة. سادساً: جهود مصر لمواجهة آثار جائحة كورونا قامت مصر باتخاذ العديد من القرارات والإجراءات لمواجهة آثار جائحة كورونا والحد منها والتئي كان لها آثاراً على قطاع السياحة ومن أهمها القرارات الآتية: تعليق حركة الطيران في كافة المطارات المصرية من 19 مارس حتى نهاية شهر مايو 2020

السماح للوفود السياحية المتواجدة في مصر أثناء مدة تعليق الطيران باستكمال برامجهم

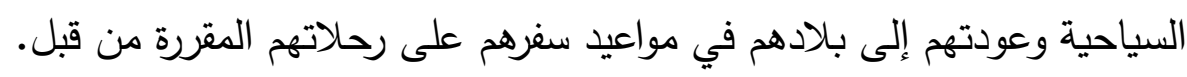
تعقيم كافة الفنادق والمنشآت السياحية في فترة تعليق الرحلات السياحية. غلق جميع المنافذ البرية بمحافظة جنوب سيناء.

غلق المطاعم والمقاهي والكافتيريات والكافيهات والكازينوهات والملاهي والنوادي والمراكز التجارية من 7 مساء حتى 6 صباحاً حتى 31 مارس. هذا بالإضافة إلى العديد من القرارات الأخرى التي تم اتخاذها من مجلس الوزئه ماءراء والبنك المركزي المصري والتي تشمل الآتي:

1. إجراءات الدعم الاقتصادي للقطاع السياحي والقطاعات المرتبطة بها

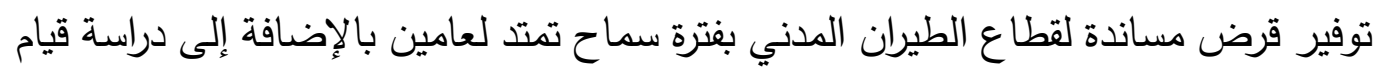

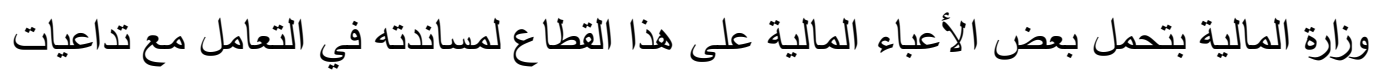
الظروف الراهنة.

قيام البنك المركزي بدراسة لتقديم تمويل للمنشآت السياحية والفندقية لتحويل العملية التشغيلية بهدف الاحتفاظ بالعمالة على أن يكون بفائدة مخفضة. قرار البنك المركزي بتأجيل سداد كل الالتزامات وأقساط القروض لفأدة حتى الثخصية لمدة 6 
تأجيل سداد الضريبة العقارية المستحقة على المنشآت السياحية لمدة 3 أشهر والسماح بتقسيط الضريبة العقارية المستحقة على المنشآت السياحية عن الفترات السابقة من خلال أقساط

$$
\text { شهرية لمدة } 6 \text { أشهر. }
$$

تم تأجيل سداد مبلغ 41.8 مليون جنية قيمة باقي حصيلة الدولة من أرباح الثركة القابضة

$$
\text { للسياحة والفنادق عن العام الماضي. }
$$

التتسيق بين وزارة السياحة والاتحاد المصري للغرف السياحية على تتفيذ مبادرة لدعم الفئات

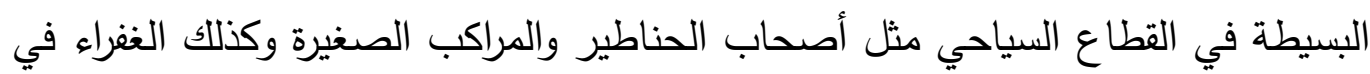
المواقع السياحية المختلفة.

إنشاء صندوق للأزمات لدعم العاملين في القطاع السياحي يستهدف دعم العمالة ألفندقية

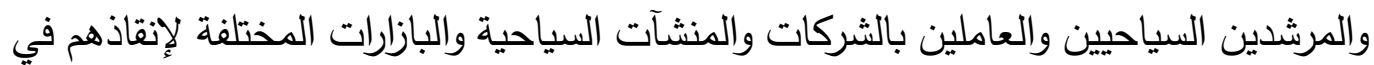

$$
\text { أوقات الأزمات. }
$$

2. إجراءات دعم التنمية العقارية في القطاع السياحي:

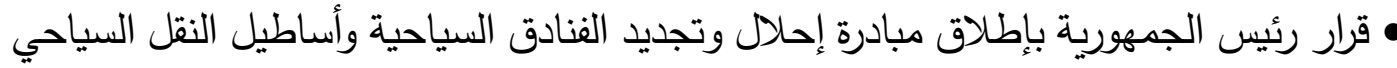
ورفع كفاءة البنية التحتية للمنشآت السياحية لتكون جاهزة لاستقبال الزائرين عقب انحصار الناريار

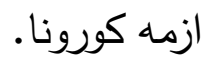

• تخصيص قطعة أرض لإقامة مرسى للمراكب النيلية على الكورنيش ضمن أعمال التطوير

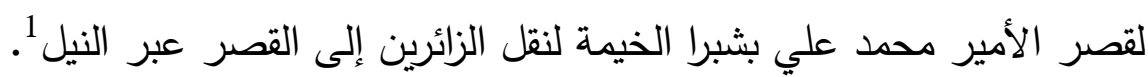

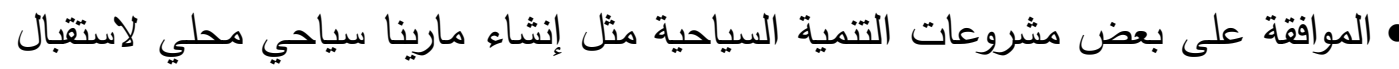
اليخوت وسفن النزهة (ميناء تخصصي) بخليج أبو سومة، بمحافظة البحر الأحمر².

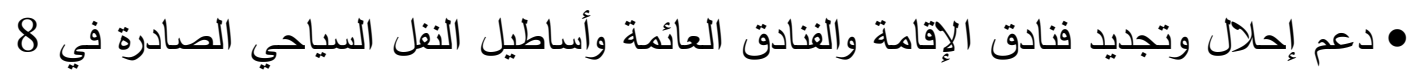

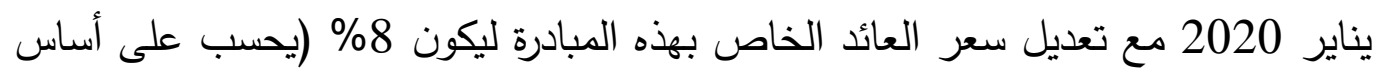

$$
\text { متناقص) بدلا من 10\% }
$$

3. إجراءات دعم العاملين بالقطاع السياحي: بأل

قامت الدولة بالعديد من الجهود التقليل آثار الأزمة على العاملين بالقطاع من خلال غرفتي الثركات السياحية والمنشآت ألفندقية والتي تشمل الآتي:

مإنشاء قاعده بيانات عن عدد العاملين المؤمن عليهم بكل منشأة وحجم رواتبهر. • التوجيه بالحفاظ على العمالة في القطاع السياحي وكذللك قطاع النقل السياحي والنقل الجوي. 
• بدأ مجموعة دورات تدريبية مجانية للعاملين بالشركات "أون لاين" باستخدام برنامج Zoom

.Meeting

• صرف إعانات الطوارئ للعاملين في قطاع السياحة من العمالة المنتظمة وغير المنتظمة. 4. استكمال أعمال الترميم والتطوير للمناطق الأثرية والسياحية وإلمناطق المحيطة:

• مشروع تطوير بحيرة عين الصيرة والمناطق المحيطة والتي يقع على ضفافها متحف التفئ

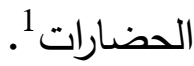

• تطوير ميدان التحرير، والذي تم تزينه بالمسلة الفرعونية التي تم نقلها من صان الحجر،

بالإضافة لأربعة كباش من خلف معبد الكرنك التي سوف يتم ترميمها.

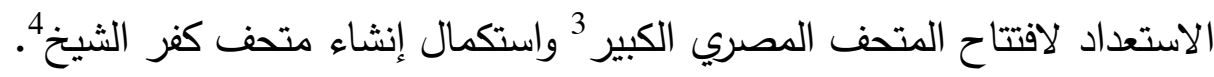

استكمال أعمال تطوير الدحميات الطبيعية.

استمرار التنقيب على الآثار والاكتثافات الحديثة.

5. الترويج السياحي باستخدام التكنولوجيات الحديثة:

• أطلقت وزارة السياحة والآثار مبادرة تحت شعار "اكتثف مصر من بيتك \# Home From

إطلاق جولات افتراضية ورحلات إشادية للمناطق الأثرية والمتاحف عبر الصفحات الصات الرسمية

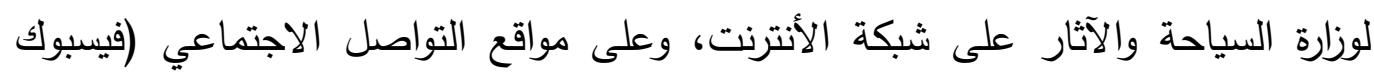

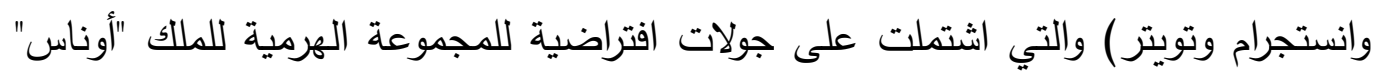
ومقبرتي "محو" و"واحتي" بمنطقة سقارة، وعرض لروائع ألفن الإسلامي. بالإضافة إلى رحلة الفية إرشادية بالمتحف الكبير ك. الترويج للثقافة المحلية التراثية والأثرية: بالثيثة

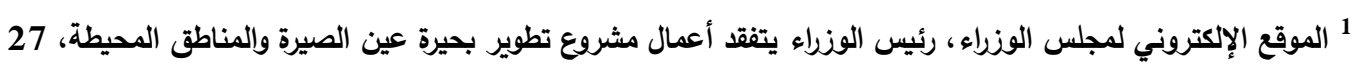

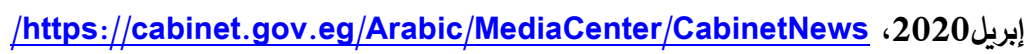
2 الموقع الإكتروني لمجلس الوزراء، رئيس الوزراء يُتابع من الموقع الموقف النهائي لأعمال تطوير ميدان التحرير، 27

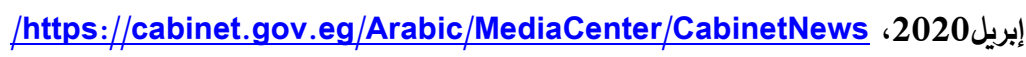
3 بوابة الأهرام الإكترونية المتحف المصري الكبير يستقبل 42 قطعة خثبية من مركب خوفو الثانية، 2 مايو 2020، http://gate.ahram.org.eg/News/2406536.aspx

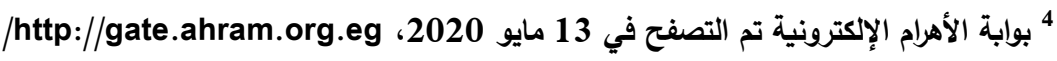
5 بوابة الأهرام الإكترونية، صحف ووكالات أنباء عالمية تثيد بمبادرة ونائ وزارة السياحة والآثار "اكتثف مصر من بيتك"، 24 إبريل http://gate.ahram.org.eg/News/2399642.aspx 2020 / بوابة الأهرام الإكترونية تم التصفح في 13 مايو 2020، 
- إطلاق وزارة السياحة والآثار سلسلة حلقات مصورة عن التراث والتاريخ المصري القديم عبر شبكة التواصل الاجتماعي الفيسبوك 1.

- متحف النسيج ينظم مسابقة فنية على شبكة التواصل الاجتماعي فيسبوك تحت عنوان "عالم واحد"، والتي تشمل قسمين الأول لرسم لوحات إرشادية تحمل عبارات تحث المواطنين على الالتزام بالمنازل واتباع العادات الصحية السليمة للحفاظ على الصحة العامة، والثانية مسابقة للتصوير الفوتوغرافي تعبر موضوعاتها عن التضامن الإنساني وقيمة الحياة واختلاف أنماطها في ظل أزمة الفيروس. - إطلاق فيديو عن تاريخ الطبخ في مصر لبعض الوصفات الفرعونية التي وجدت على جدران المعابد2

\section{fid $\Omega_{1}$} LIFE, PROSPERITY, HEALTH
6. إطلاق علامة السدلامة الصحية للفنادق والتي اعتمدتها وزارة السياحة والآثار والتي يجب توافرها بجميع الفنادق الراغبة في التشغيل، مما يفيد تطبيقها للضوابط والشروط المعتمدة من مجلس ولس الوزراء ووفقاً للمعايير الصحية العالمية.3 3

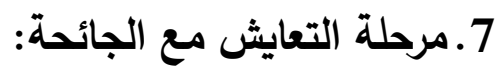

قرار مجلس الوزراء من خلال اجتماع ثلاثي بين وزراء الطيران والسياحة والصحة4 بالسماح باستئناف السياحة الداخلية وتشغيل المنشآت ألفندقية بنسبة 25\% من الطاقة الاستيعابية للفنادق اعتبارا من 15 مايو 2020، ترتفع إلى 50\% اعتبارا من أول يونيو 2020. مع اتخاذ كافة الإجراءات الاحترازية داخل الفنادق، والحفاظ على تطهير وتعقيم كافة مناطق العمل، ووضع الإرشادات التوعية في كافة أماكن العمل من اجل السلامة الصحية ومنع انتشار العدوي.

تواصل الاتحاد المصري للسياحة مع بيت خبرة عالمي لإعداد استراتيجية طويلة المدي لتطوير القطاع السياحي.

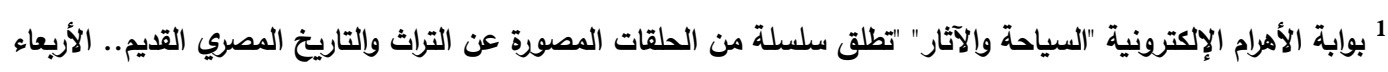

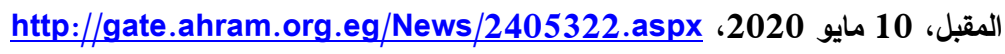

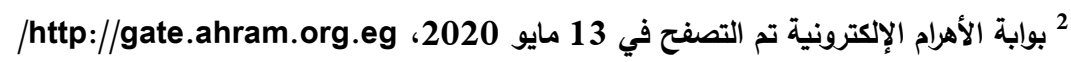

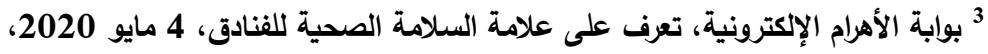
http://gate.ahram.org.eg/News/2403266.aspx 4 بوابة الأهرام الإكترونية، وزراء الطيران والسياحة والصحة يبحثون إجراءات العمل في ظل تداعيات فيروس كورونا، 4 مايو http://gate.ahram.org.eg/News/2403292.aspx ،2020 
سابعاً: السيناريوهات المتوقعة للقطاع السياحي المصري خلال عام 2020

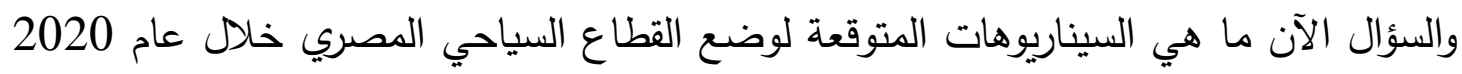

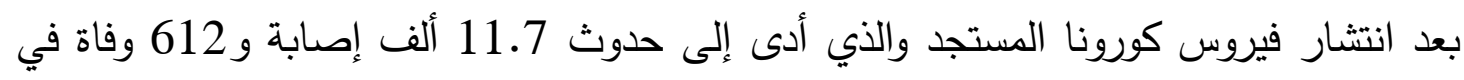

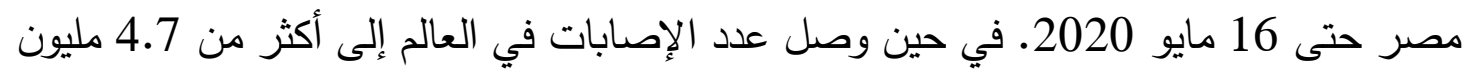

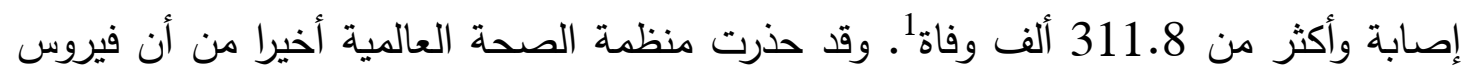
كورونا المستجد سوف يستغرق عدة سنوات حتى يتم احتوائه بالكامل وأنه لا بد من العمل بجدية للوصول إلى مصل فعال في أسرع وقت للحد من استمرار تفشي هذا الفيروس القاتل.

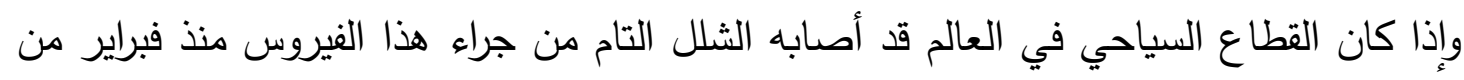

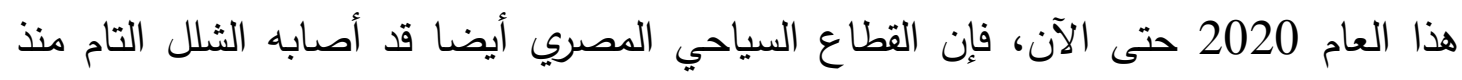

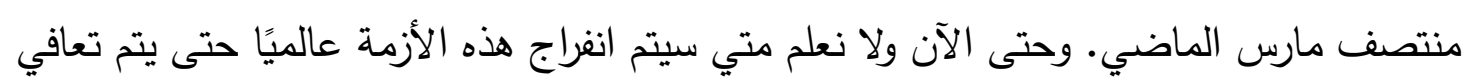
قطاع السياحة المصري.

لذلك سوف يتم وضع بعض السيناريوهات التي يمكن أن تساعد في الوصول إلى بعض التوقعات الخاصة بالقطاع السياحي المصري بعد انفراج هذه الأزمة العالمية وهذا طبقا لثلاثة سيناريوهات.

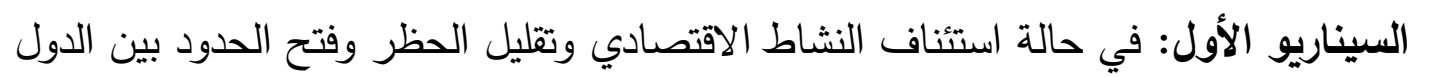
المختلفة وخاصة الدول الأوروبية. وبدء رحلات الطيران الخارجي والتي من الدتوقع إن تكون

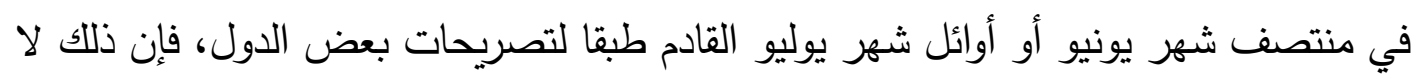
يعني استئناف النشاط السياحي بشكل مباشر وبسرعة. وذللك بسبب الظروف الاقتصادية الصعبة لتصنية التي تمر بها معظم دول العالم نتيجة لتفشي هذا الفيروس وتأثيره الثديد على الاقتصاد، نتيجة لوقف الإنتاج فيها وكذللك بسبب تخوف السكان حول العالم من السفر خوفاً من خطر العدوي. مما أدى إلى تصريح منظمة السياحة العالمية والمجلس الدولي للسياحة والسفر بإن توقعاتهم

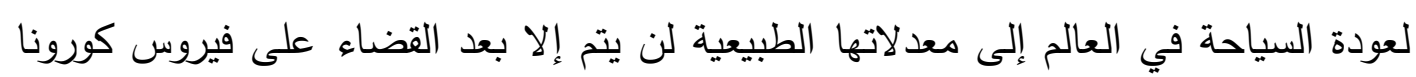
المستجد.

لذلك فإنه طبقا للسيناريو الأول إذا تم فتح الحدود بين الدول واستئناف رحلات الطيران فإن ذلك لا

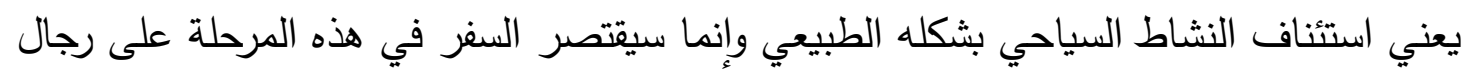

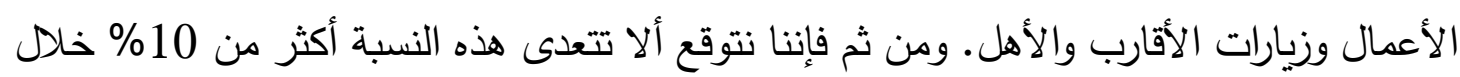

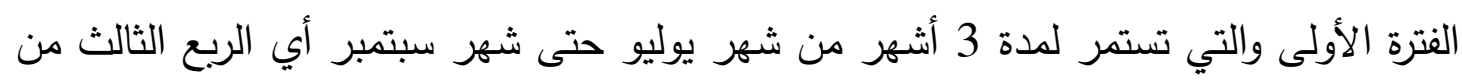

\footnotetext{
${ }^{1}$ Worldometers website, retrieved 15 May 2020 !https://www.worldometers.info/coronavirus/
} 
العام الحالي. وهذا يعني أن خسائر القطاع السياحي المصري سوف تصل إلى 90\% خلال هذه الفترة.

• السيناريو الثاني: في حالة استئناف الحياة الطبيعية وكذللك النشاط السياحي في العالم خلال الربع الأخير من عام 2020 (أكتوبر - ديسمبر ) ومع استمرار وجود فيروس كورونا في معظم ولان

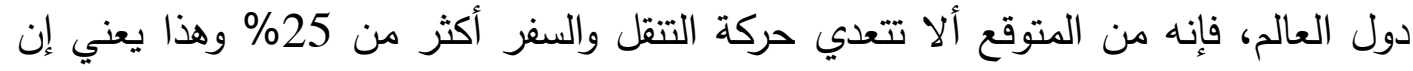

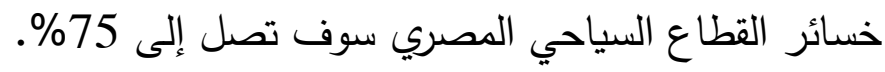

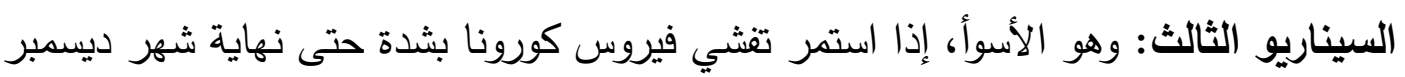

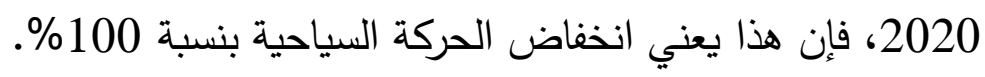
ولتوضيح الخسائر التي يمكن إن يتعرض لها القطاع السياحي المصري طبقا للسيناريوهات السابقة يمكن القول إنه طبقا للسيناريو الأول (التعافي بداية من الربع الثالث من هذا العام) فإن الخسارة

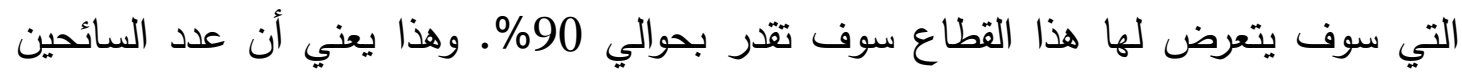

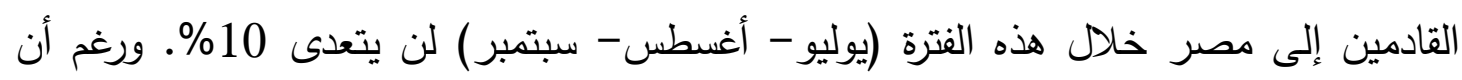
التوقعات كانت تثير إلى أن أعداد السائحين القادمين إلى مصر خلال هذا العام 2020 سوف إنى

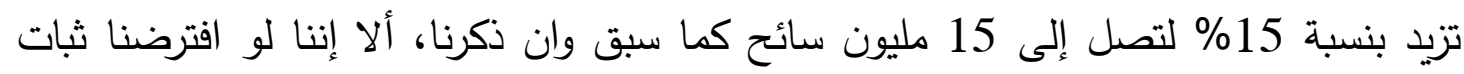

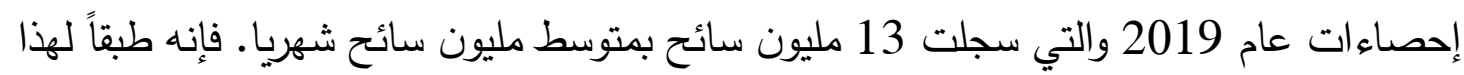
السيناريو فإن عدد السائحين خلال الريع الثالث من عام 2020 لن يتعدى 300 ألف سائح سئح

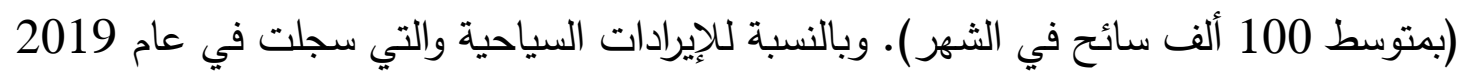

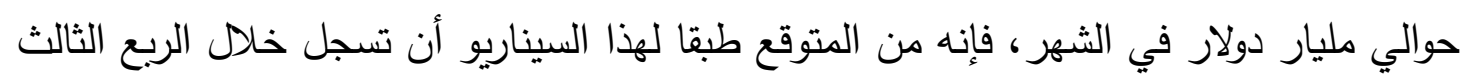

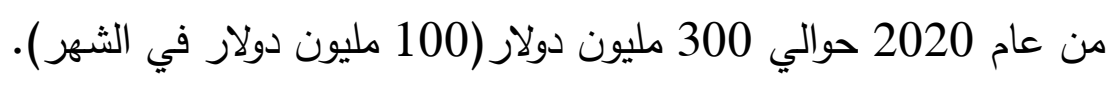

أما الرابع والأخير في عام 2020 (أكتوبر -نوفمبر -ديسمبر ) فإنه الخسارة التي سوف يتعرض لها

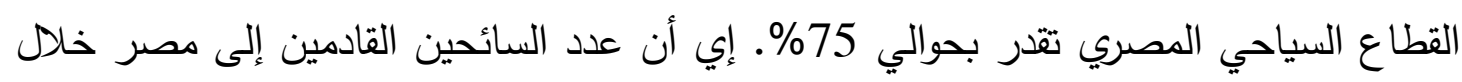

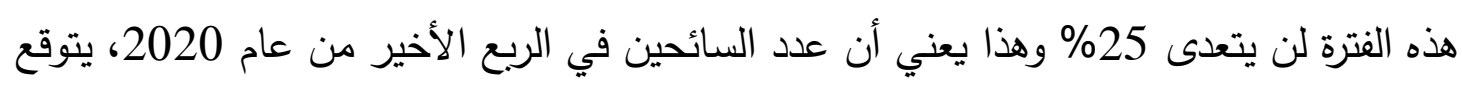

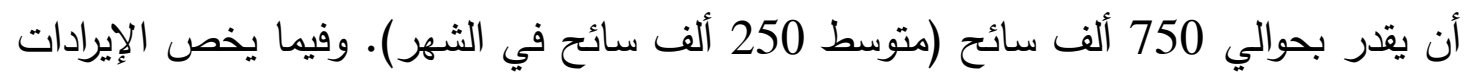

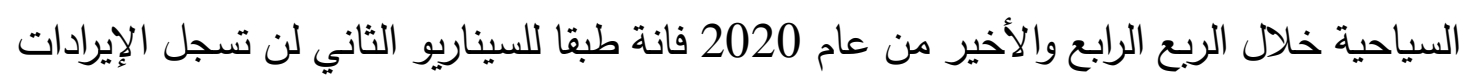

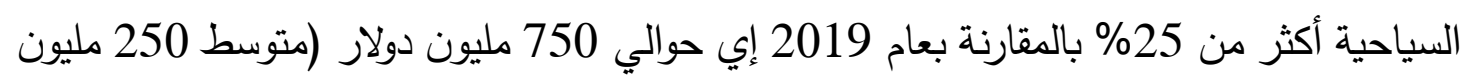

$$
\text { دولار في الشهر). }
$$

ومما سبق نستطيع القول إن أعداد السائحين في عام 2020 سوف تقدر بحوالي 3.45 مليون سائح بانخفاض قدرة 73.5\% عن عام 2019. في حين إن الإيرادات السياحية في هذا العام

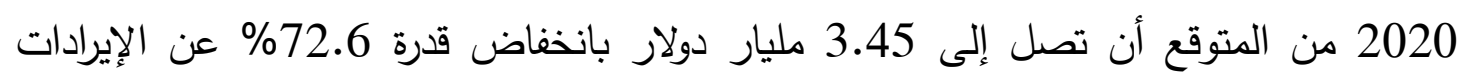


السياحية في عام 2019. مما يعني أن القطاع السياحي خلال عام 2020 من المتوقع إن يسجل

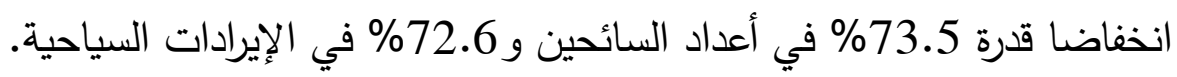
وطبقا للسيناريو الثاني وهو التعافي بداية من الربع الرابع والأخير فقط (أكتوبر - ديسمبر) فان

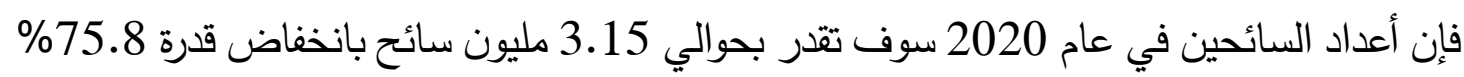

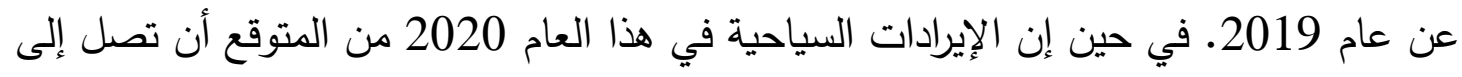

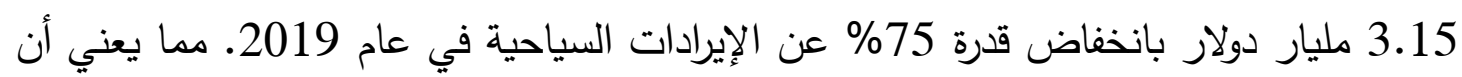
القطاع السياحي خلال عام 2020 من المتوقع إن يسجل انخفاضا قدرة السائحين و 75\% في الإيرادات السياحية.

وبالنسبة للسيناريو الثالث والذي يتوقع عدم تعافى القطاع السياحي العالمي قبل نهاية ديسمبر

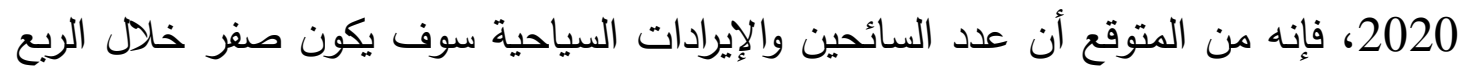

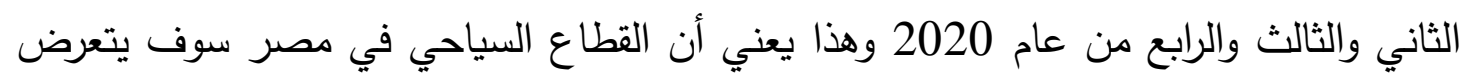
لخسارة كبيرة لمدة 9 أشهر ونصف من عام منصف مارس إلى ديسمبر من عام 2020. وسيقصر نشاط هذا القطاع على ما سجله في الربع الأول من عام 2020 والذي يقدر ب بن 2.4 مليون سائح وإيرادات تقدر بحوالي 2.4 مليار دولار.

وأخيراً يمكن القول إن انخفاض أعداد السائحين ومن ثم الإيرادات السياحية، سوف يؤدي إلى الى

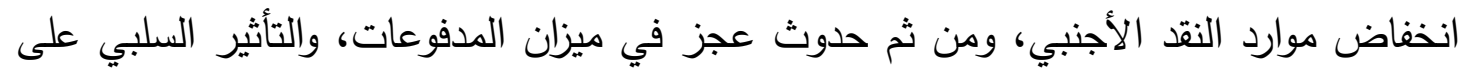

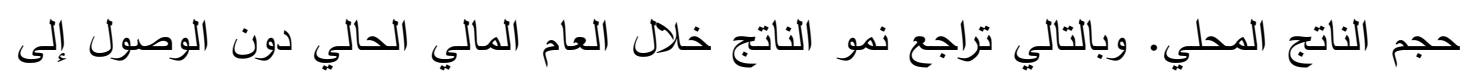

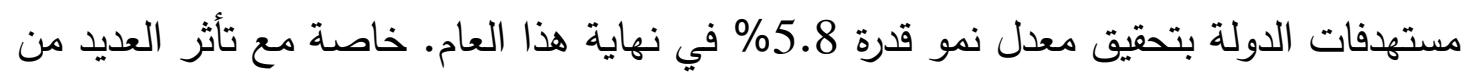

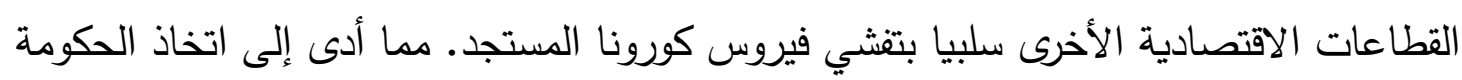
العديد من الإجراءات لمساعدة القطاع السياحي على التعافي سريعا فور انتهاء هذا الوباء. ثامناً: بعض المقترحات للتخفيف من آثار الأزمة على القطاع السياحي

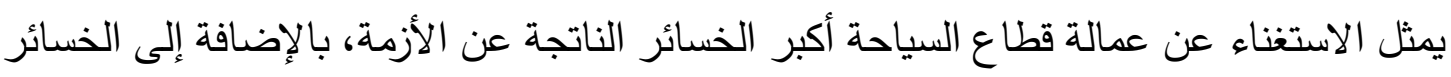

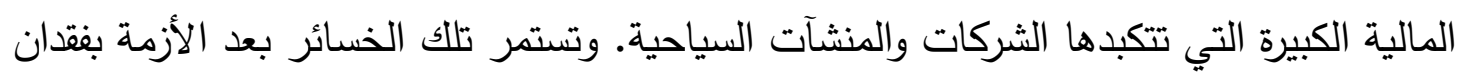
العمالة الماهرة والمدربة بعد تحول العمالة السياحية للعمل في مجالات أخري بحثا عن دخل ثابت التئل

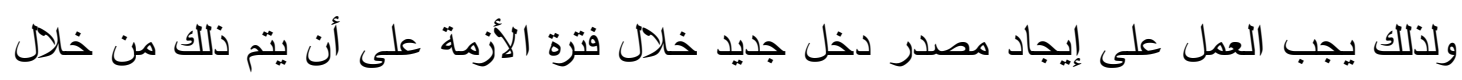
تتمية مهارات العمالة السياحية كل في مجال تخصصده، بالإضافة إلى العمالة الداعمة لنشاط القطاع السياحي مثل قطاع النقل والترفيه. 
ونتيجة للازمة تحول الكثير من العاملين في بعض القطاعات لنظام العمل من المنزل من خلال

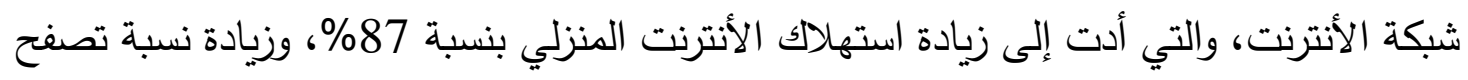

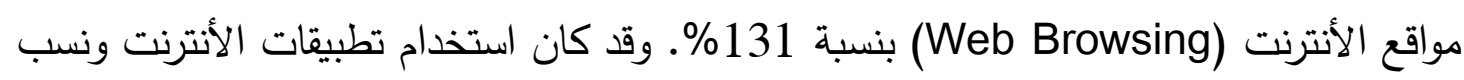

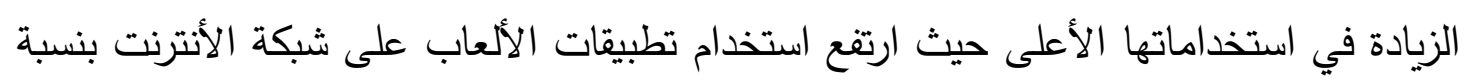

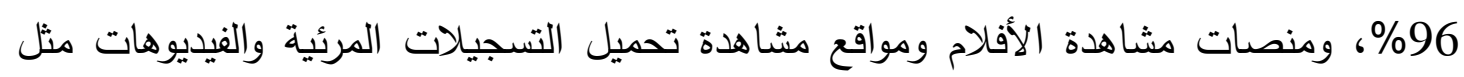

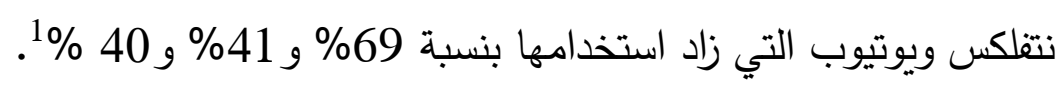

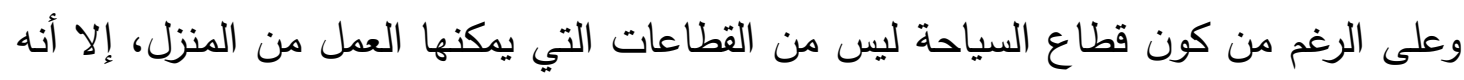

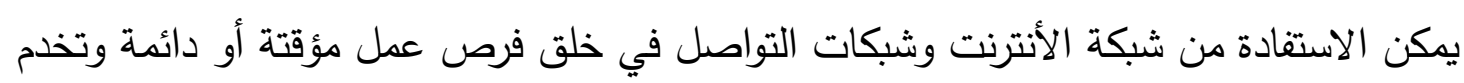
قطاع السياحة الآن ولاحقا والتي تثمل الآتي:

\section{1.الاستفادة من العاملين في وكالات السفر في إجراءات مواجهة الأزمة ولادئ} يمكن للعاملين في وكالات السفر والدعاية والذين يمتلكون المعرفة والخبرة في استخدام اللغات المختلفة أن يقوموا بالعمل في مراكز اتصال Call Centre لتقديم خدمات ومعلومات حول جائحة

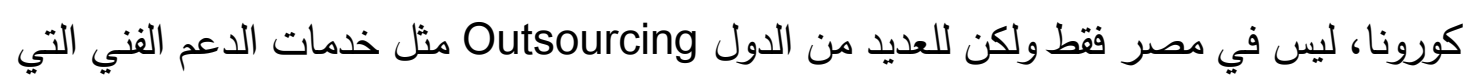

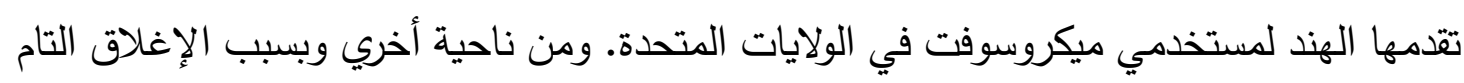

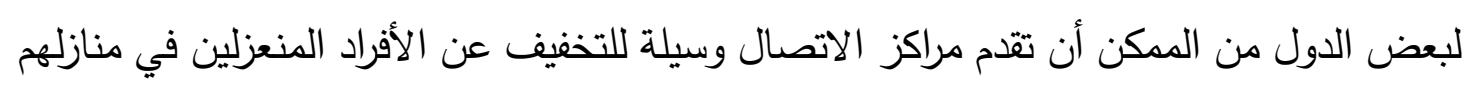
لعدم الإصابة بالتوتر والقلق.

\section{2.فرص بديلة للمرشدين السياحيين بما يساعد في الترويج للسياحة المصرية}

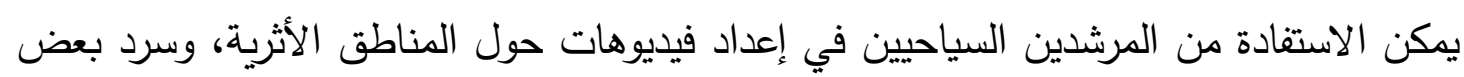

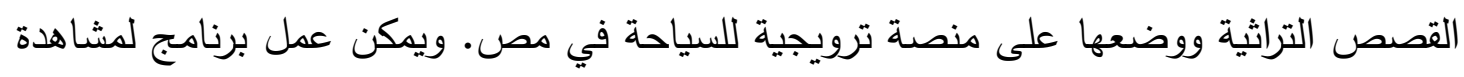

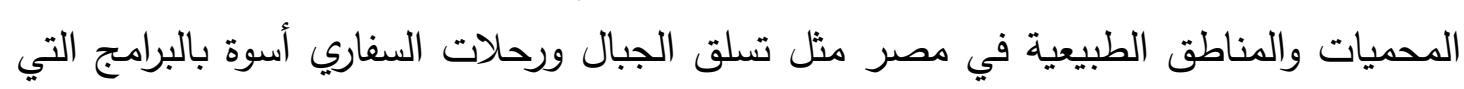
تذاع على قناة ناشونال جيوجرافيك.

\section{3. إيجاد فرص بليلة لتثغيل وسائل النقل السياحي}

اشتراك شركات النقل السياحي بشكل مؤقت مع شركات المواصلات الحديثة مثل أوبر وسويفيل،

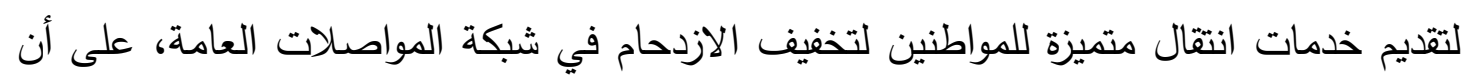
تكون بتكلفة مميزة للحفاظ على أصول تلك الثركات بعد عبور الأزمة.

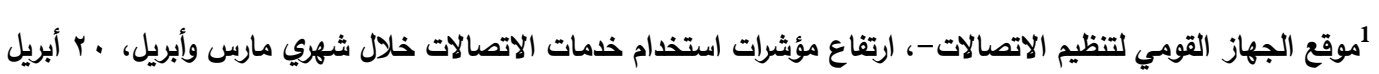
/https://tra.gov.eg/ar/media-center/press-releases r. r. 


\section{4. الترويج السياحي باستخدام الوسائل الحديثة}

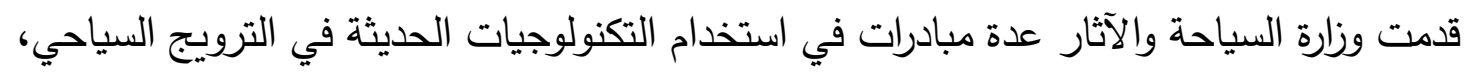

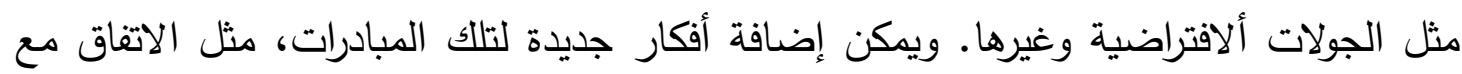

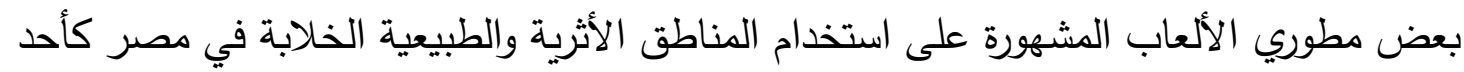
البيئات الموجودة على الألعاب مما يثير رغبه المستخدمين على زيارة هذه الأماكن مستقبلاً.

شكل رقم (5) تصميم البيئات الاخلية لأحدى الألعاب بما يحاكي بعض المناطق الأثرية
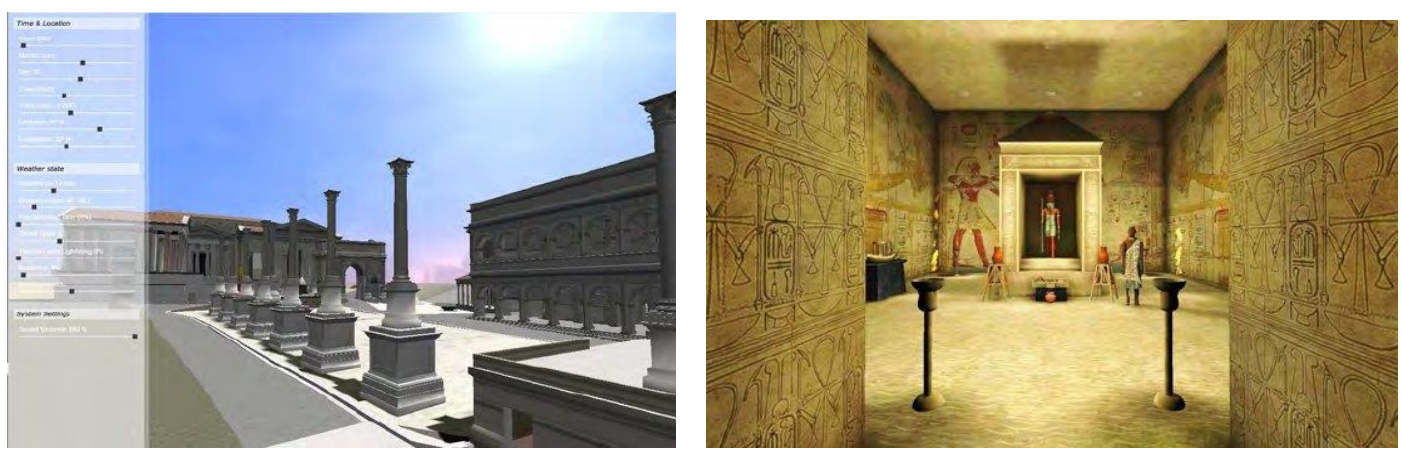

Anderson \& Others. (2010 .(Developing serious games for cultural heritage: a stateof-the-art review . Virtual Reality.

\section{التسوق للمنتجات الحرفية عبر منصات إلكترونية}

من القطاعات المتضررة البازارات ومحلات بيع التذكارات ومنتجات الحرف التراثية، ويمكن تسويق منتجاتها عبر منصة للحرف التراثية وتوصيلها من خلال شركات البيع الإكتروني مثل أمازون.

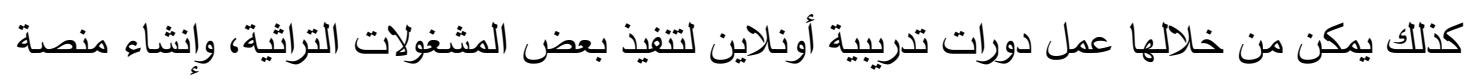

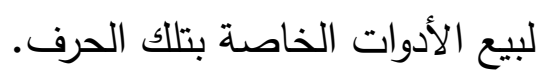

\section{شكل رقم (6) تدريب على المشغولات التراثية}
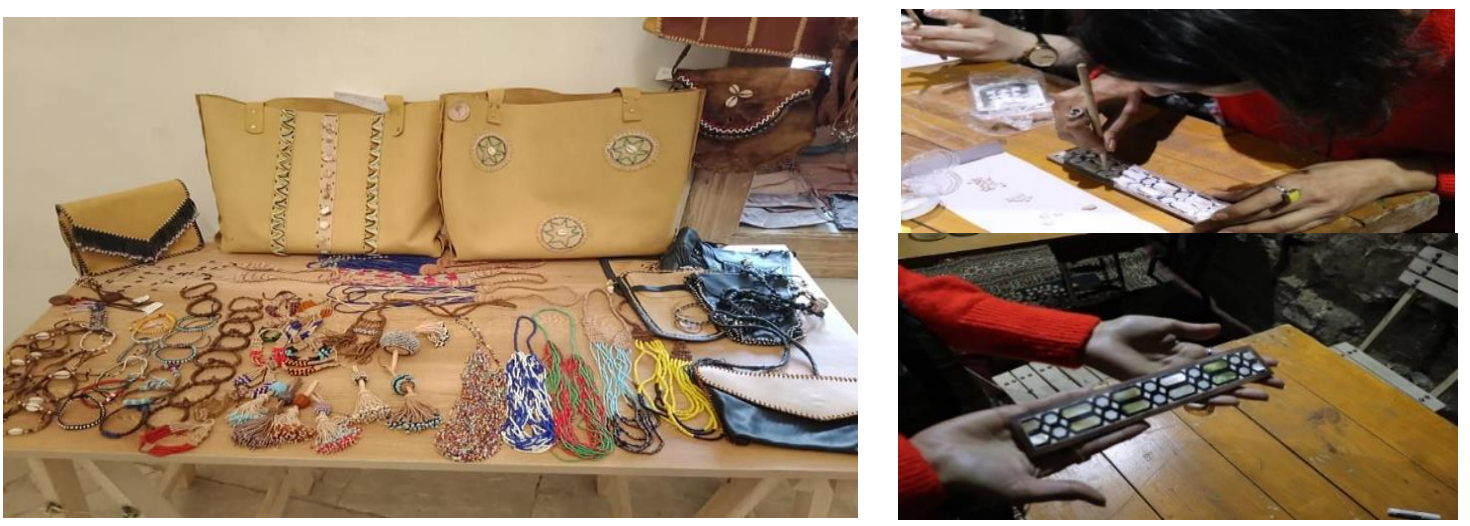

المصدر: Built Environment Collective) Facebook page, retrieved 14 ) Megawra

May 2020 
5. إطلاق العلامة المميزة لبعض المناطق والحرف التراثية المصرية Branding

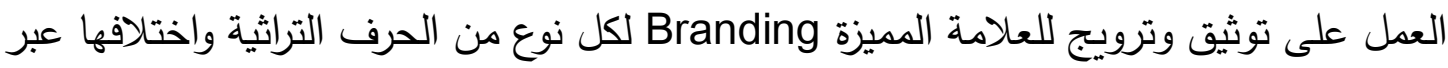
مناطق ومحافظات مصر من خلال حلقات مصورة لتاريخ وتنوع تلك الحرف. وقد قامت مصر بالفعل بعمل أطلس للحرف اليدوية يضم توزيع الحرف المختلفة على كافة المحافظات المصرية

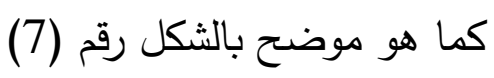
شكل رقم (7) أطلس الحرف اليدوية - محافظة الفيوم
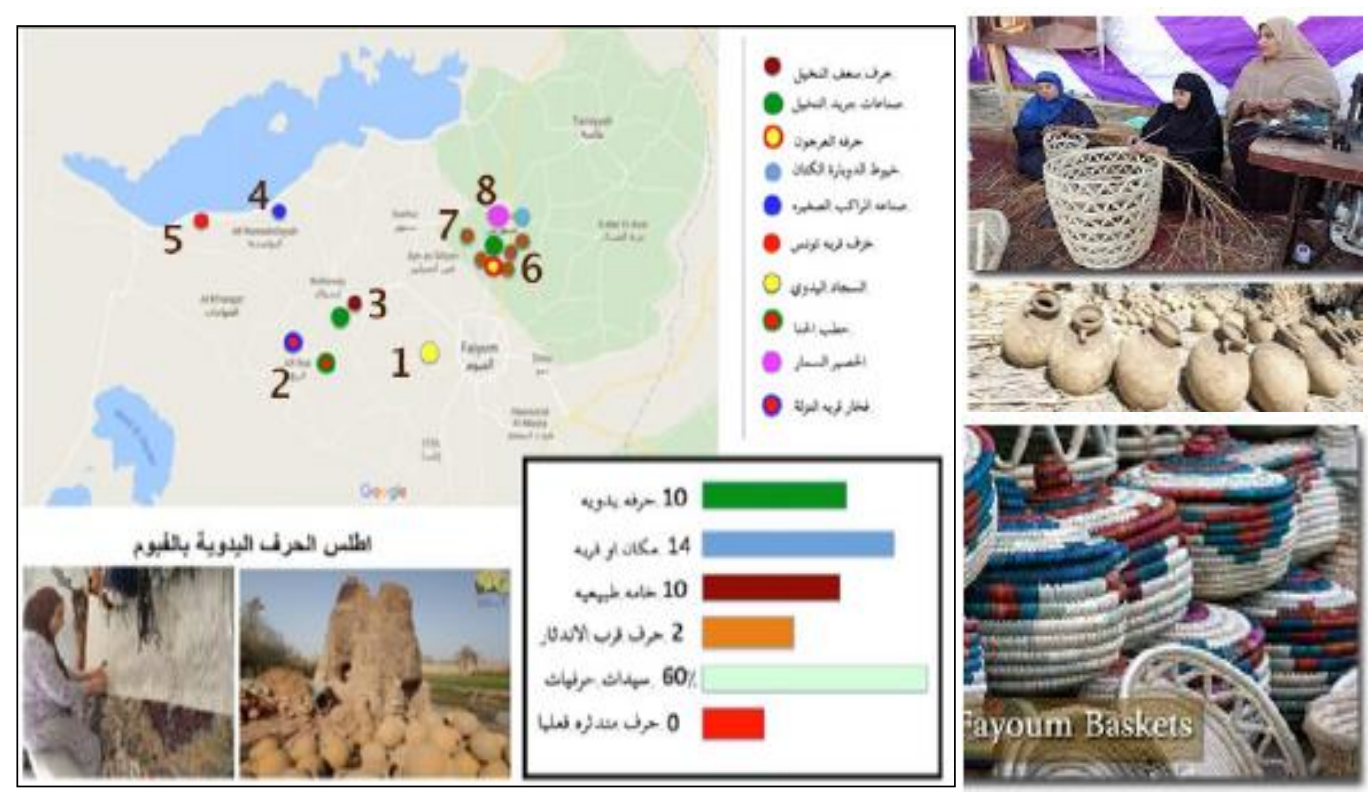

المصدر : الموقع الإلكتروني لجريدة مصر العربية، أطلس الحرف اليدوية.. أول دليل مبسط لإبداعات المصريين في 20 محافظة، 14 ديسمبر 2019، masralarabia.net.www.

6. الاستعداد لما بعد الأزمة من أهم أنواع السياحة التي من الممكن الترويج لها قبل زوال الأزمة هي السياحة البيئية التي تمتاز بانخفاض الكثافة والتواصل مع الطبيعية. 7. رفع الوعي الصحي للعاملين في مجال السياحة لابد من رفع الوعي بالممارسات الصحية المطلوبة لمواجهة الفيروسات واعتمادها ضمن المهارات الأساسية للعاملين في قطاع السياحة، وذلك من خلال دورات تدريبية مكثفة لكافة العاملين بالقطاع. 
أدى انتثار فيروس كورونا المستجد إلى تضرر العديد من القطاعات الاقتصادية والإنتاجية على

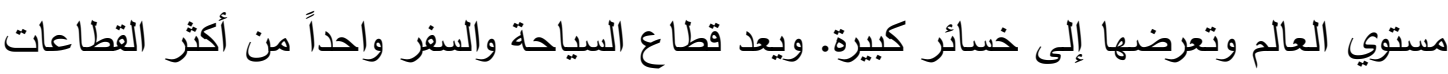
الاقتصادية التي تكبدت خسائر فادحة نتيجة انتشار فيروس كورونا، حيث توقفت حركة السياحة

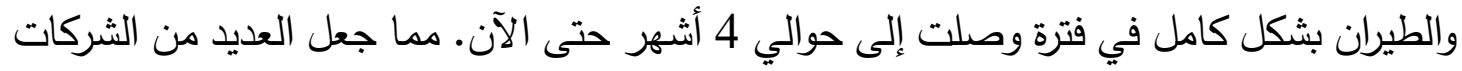

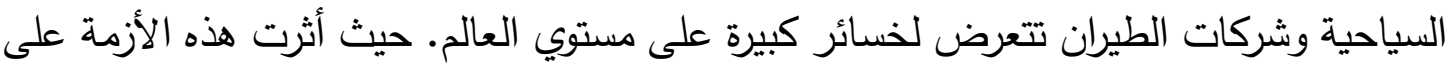

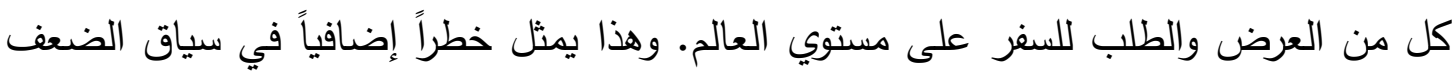
الطارئ على الاقتصاد العالمي والتوترات الجيوسياسية والاجتماعية والتجارية. بالإضافة إلى الأداء

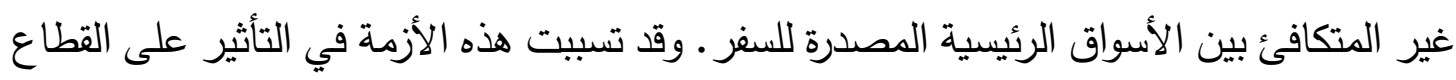

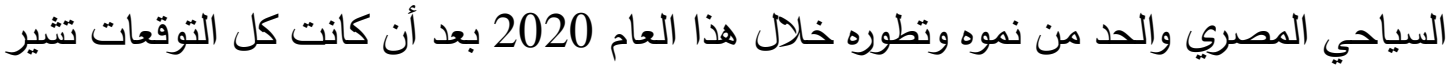

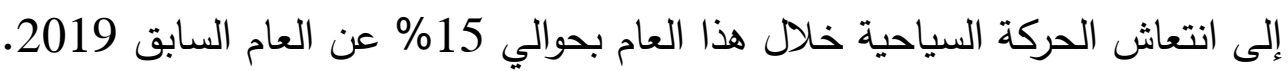
لذلك أصبح القطاع السياحي اليوم في تحدٍ جديد يعتبر الأسوأ من نوعه جراء تفشي فيروس كورونا

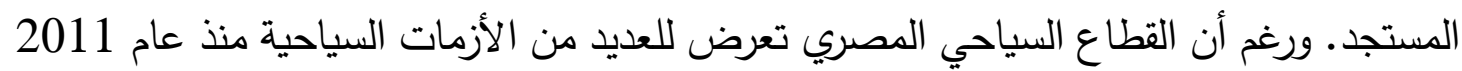

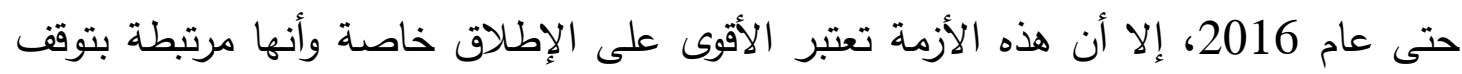

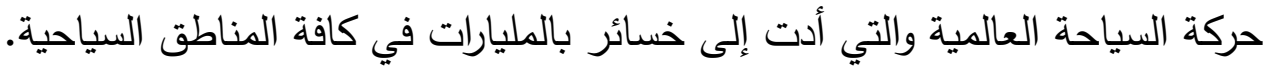
وقد قامت الحكومة المصرية بإصدار العديد من القرارات والإجراءات للحد من التأثيرات السلبية

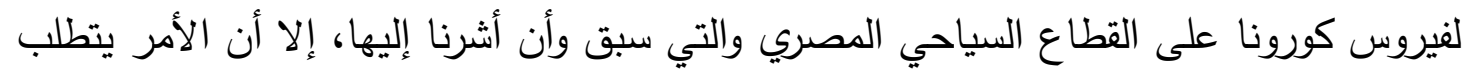

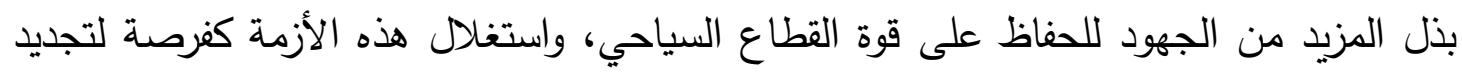
وتطور وزيادة قدرته على المنافسة الدولية ومساعدته على النهوض سريعا بمجرد انتهاء هذه الأزمة. وهذا يتطلب حسن إدارة هذه الأزمة والحفاظ على العاملين في هذا القطاع بجميع فئاتهم، ودعم

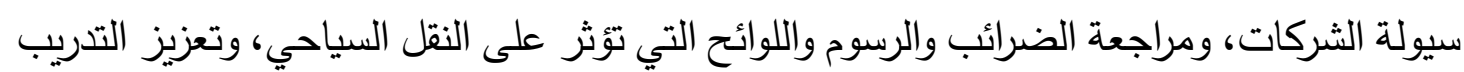
وتتمية المهارات وخاصة المهارات الرقمية. هذا بالإضافة إلى إدراج القطاع السياحي في حزم الطوارئ الاقتصادية الوطنية والإقليمية والعالمية

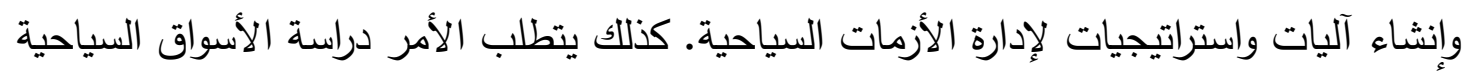

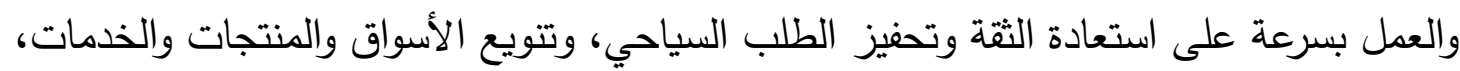
والاهتمام بأنماط سياحية جديدة مثل السياحة البيئية والسياحة العلاجية. وجدير بالأكر أن عودة السياحة الدولية سوف تعتمد على قرارات سيادية للدول المختلفة وليس على

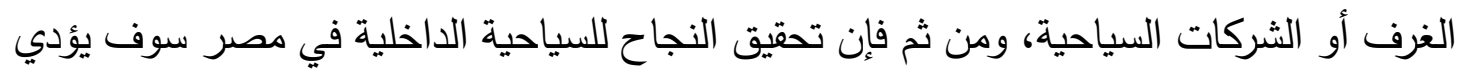


إلى منح الثقة لعودة السياحة الدولية سريعاً. وتشير توقعات خبراء السياحة العالمية إلى أن تعافي

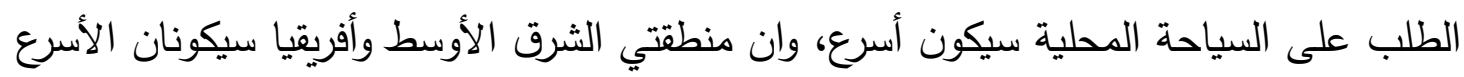
على مستوي العالم في التعافي، ويتوقع هؤلاء الخبراء أن يتم ذلك خلال الربع الأخير من هذا العام. لللك لا بد من الآن التعاون بين كل من وزارة السياحة والآثار والاتحادات والثركات السياحية لإعداد خططاً تسويقية ترويجية تتناسب مع العديد من الأسواق، مع مراعاة الظروف الطارئة

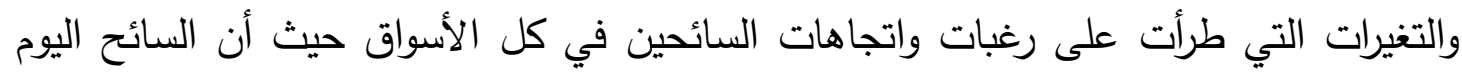

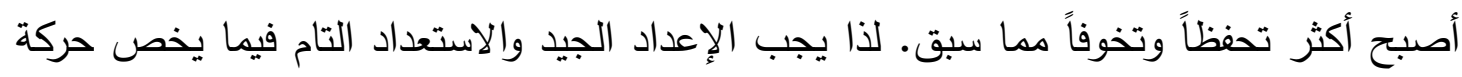
السياحة الدولية القادمة من حيث استعداد المطارات وحركة نقل السياح وأماكن الإقامة والمزارات والمراكز الطبية وغير ذلك من الاستعدادات الأخرى. 


\section{المراجع}

أولاً: مراجع بالغة العربية

• البنك المركزي المصري، النشرة الإحصائية الثهرية، أعداد مختلفة.

• الجهاز المركزي للتعبئة العامة والإحصاء، مصر في أرقام 2020.

• مؤتمر الأمم المتحدة للتجارة والتنمية (UNCTAD)، السياحة المستدامة: المساهمة في النمو الاقتصادي والتنمية المستدامة. جنيف 2013.

• منظمة السياحة العالمية، الحرص على فرص العمل ودعم الاقتصاد بواسطة السفر والسياحة- دعوة للعمل

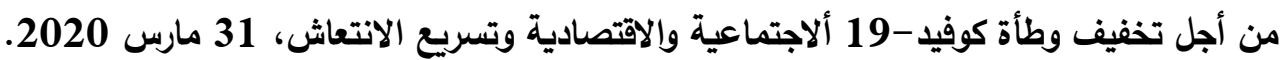

\section{ثانياً: مراجع باللغة الأجنبية}

- $\quad$ Anderson, E. F ‘.Mcloughlin, L., Liarokapis, F., Peters, C., Petridis, P \& ‘.Freitas, S. D . .(2010)Developing serious games for cultural heritage: a state-of-the-art review .Virtual Reality .275-255 ، (4) 14 ،doi: 10.1007/s10055-010-0177-3

- International Air Transport Association (IATA), Air Passenger Market Analysis, March 2020

- $\quad$ Travel \& Tourism Council 'WTTC now estimates over 100 million jobs losses in the Travel \& Tourism sector - and alerts G20 countries to the scale of the crisis 'Press Release 24 April 2020

- $\quad$ World Tourism Organization, UNWTO :INTERNATIONAL TOURISM ARRIVALS COULD FALL BY 20-30\% IN 2020, NEWS RELEASE, 27 MAR 2020

- World Tourism Organization, UNWTO World Tourism Barometer- Special focus on the Impact of COVID-19 ،May 2020

ثالثاً: المواقع الإلكترونية

www.cbe.org.eg الموقع الإكتروني للبنك المركزي المصري، سلاسل زمنية، 10 مايو

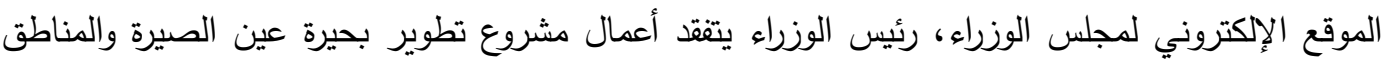
/https://cabinet.gov.eg/Arabic/MediaCenter/CabinetNews 2020، المحيطة، 27 إبريل الإنيل الموقع الإكتروني لمجلس الوزراء، رئيس الوزراء يُتابع من الموقع الموقف النهائي لأعمال تطوير ميدان

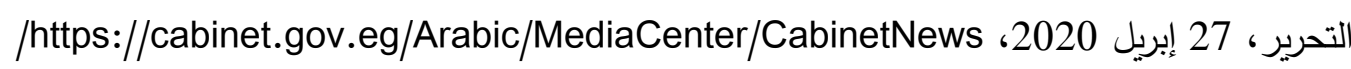

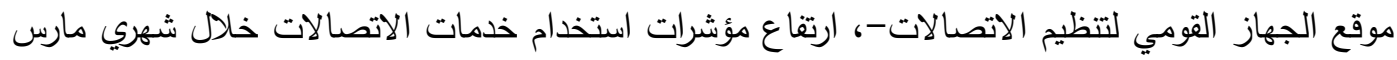

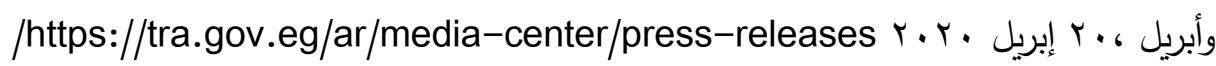
بوابة الأهرام الإكترونية تعرف على قرارات الحكومة في اجتماعها اليوم، 13 مايو 2020، http://gate.ahram.org.eg/News/2406536.aspx بوابة الأهرام الإكترونية، المتحف المصري الكبير يستقبل 42 قطعة خشبية من مركب خوفو الثانية، 2 مايو http://gate.ahram.org.eg/News/2406536.aspx 2020 /http://gate.ahram.org.eg 2020، 13 ماية الأهرام الإكترونية تم التصفح في 
بوابة الأهرام الإلكترونية، صحف ووكالات أنباء عالمية تثيد بمبادرة وزارة السياحة والآثار "اكتثف مصر من

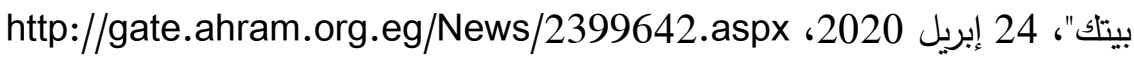
http://gate.ahram.org.eg بوابة الأهرام الإلكترونية تم التصفح في 13 مايو 2020، إلبرئ بوابة الأهرام الإكترونية "السياحة والآثار" "تطلق سلسلة من الحلقات المصورة عن التراث والتاريخ المصري

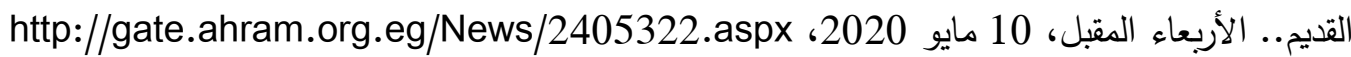
/http://gate.ahram.org.eg بوابة الأهرام الإككترونية تم التصفح في 13 مايو 2020، الاعبعاء

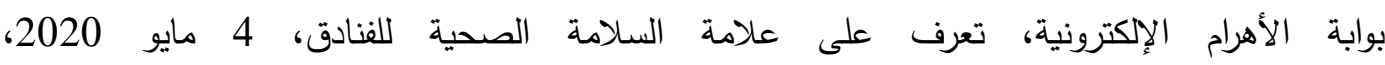
http://gate.ahram.org.eg/News/2403266.aspx بوابة الأهرام الإكترونية، وزراء الطيران والسياحة والصحة يبحثون إجراءات العمل في ظل تداعيات فيروس

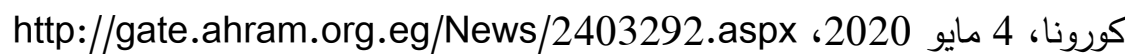
الموقع الإكتروني لجريدة مصر العربية، أطلس الحرف اليدوية.. أول دليل مبسط لإبداعات المصريين في 20 محافظة، 14 ديسمبر 2019، masralarabia.net.www .www.unwto.org ؛May 202013 retrieved ‘World Tourism Organization ؛retrieved 15 May 2020 ،Worldometers website /https://www.worldometers.info/coronavirus .Collective) Facebook page, retrieved 14 May 2020 Megawra (Built Environment 